\title{
Roles of the $\mathrm{pH}$ signaling transcription factor PacC in Wangiella (Exophiala) dermatitidis
}

\author{
Qin Wang ${ }^{1}$ and Paul J. Szaniszlo ${ }^{1,}{ }^{*}$ \\ ${ }^{1}$ Section of Molecular Genetics and Microbiology, School of Biological Sciences and Institute of \\ Cellular and Molecular Biology, The University of Texas at Austin, Austin, Texas 78712, USA
}

\begin{abstract}
To study the function of the PacC transcription factor in Wangiella dermatitidis, a black, polymorphic fungal pathogen of humans with yeast-phase predominance, the PACC gene was cloned, sequenced, disrupted and expressed. Three zinc finger DNA-binding motifs were found at the $\mathrm{N}$-terminus, and a signaling protease cleavage site at the C-terminus. PACC was more expressed at neutral-alkaline $\mathrm{pH}$ than at acidic $\mathrm{pH}$. Truncation at about 40 residues of the coding sequence upstream of the conserved protease processing cleavage site of $\mathrm{PacC}$ affected growth on a nutrient-rich medium, increased sensitivity to $\mathrm{Na}^{+}$stress, decreased yeast growth at neutral-alkaline $\mathrm{pH}$, and repressed hyphal growth on a nutrient-poor medium at $25^{\circ} \mathrm{C}$. Truncation at the coding sequence for the conserved signaling protease box of PacC impaired growth and reduced RNA expression of the class II chitin synthase gene at acidic $\mathrm{pH}$. The results suggested that $\mathrm{PacC}$ is important not only for the adaptation of $W$. dermatitidis to different ambient $\mathrm{pH}$ conditions and $\mathrm{Na}^{+}$stress conditions, but also for influencing yeast-hyphal transitions in this agent of phaeohyphomycosis.
\end{abstract}

\section{Keywords}

$\mathrm{pH}$; transcription factor; $\mathrm{Na}^{+}$stress; filamentous growth; conidiation; morphogenesis

\section{INTRODUCTION}

Wangiella (Exophiala) dermatitidis is a black polymorphic fungal pathogen of humans with yeast predominance. As an agent of phaeohyphomycosis, it causes a number of different clinical manifestations in humans ranging from chronic superficial and subcutaneous infections to rapidly progressing systemic and sometimes neurotropic infections that frequently lead to patient death (Matsumoto et al., 1994: Zheng et al., 2007). Although often referred to as an asexual black yeast species, $W$. dermatitidis is in fact a conidiogenous hyphal fungus that has been molecularly classified among the Cheatothyriomycetidae, one of the two subclasses of the Eurotiomycetes class of the Ascomycota (Geiser et al., 2006). Designation of $W$. dermatitdis as polymorphic instead of dimorphic is because it can grow not only as polarized yeast and hyphae, but also can grow in a nonpolarized, isotropically-enlarging mode that produces a number of additional morphotypes called sclerotic cells, planate cells and sclerotic bodies depending on whether they have no internal septa, one internal septum or multiple

(C) 2009 Elsevier Inc. All rights reserved.

*Corresponding author, Phone: (512) 471-3384. Fax: (512) 471-7088. E-mail: pjszaniszlo@mail.utexas.edu.

Publisher's Disclaimer: This is a PDF file of an unedited manuscript that has been accepted for publication. As a service to our customers we are providing this early version of the manuscript. The manuscript will undergo copyediting, typesetting, and review of the resulting proof before it is published in its final citable form. Please note that during the production process errors may be discovered which could affect the content, and all legal disclaimers that apply to the journal pertain. 
intersecting internal septa, respectively (Szaniszlo, 2002; Abramczyk et al., 2009). The ability of the morphotypes of pathogenic fungi to switch from one growth form to another has long been postulated to be a virulence determinant, although the evidence for this with $W$. dermatitidis is lacking. Nonetheless, because the polymorphism of $W$. dermatitidis can be induced in vitro by different conditions, and more than 100 other black fungi produce one or more similar morphotypes in vivo during human infections, this species is considered a model for their study (Szaniszlo, 2002). For example, under nitrogen limiting conditions $W$.

dermatitidis usually produces hyphal growth. In contrast, when grown in most rich media at near neutral $\mathrm{pH}$ the yeast morphotype prevails, whereas when cultured in the same rich media, but at $\mathrm{pH} 2.5$ with adequate calcium or at $\mathrm{pH} 6.5$ with limited calcium, $W$. dermatitidis produces sclerotic-form growth (Karuppayil and Szaniszlo, 1997; Szaniszlo, 2002). In addition, CDC42 encodes a Rho/Rac member of small GTP-binding proteins in $W$. dermatitidis, and the dominant active mutation $C D C 42^{G 14 V}$ activates sclerotic growth at $37^{\circ} \mathrm{C}$, and represses the filamentous growth of the temperature-sensitive hyphal form mutant $\mathrm{Hf} 1$ (Ye and Szaniszlo, 2000). Recently the APSES transcription factor StuAp and the general transcriptional repressor Tup $1 p$ have also been found to be important for the regulation of hyphal growth in $W$. dermatitidis (Liu et al., 2008; Wang and Szaniszlo, 2007).

In the manner of $W$. dermatitidis, many other fungi are known to grow in a wide range of $\mathrm{pH}$. Under these conditions, $\mathrm{pH}$ signaling transcription factors play essential roles in maintaining different gene expression patterns. Among filamentous fungi, PacC sometimes acts as a transcription factor in a pH signaling pathway (Penalva and Arst, 2004; Penalva et al., 2008). When ambient $\mathrm{pH}$ is elevated, $\mathrm{PacC}$ expression is induced with the result that other genes are activated or repressed by the induced PacC. PACC constitutive mutants $\left(\mathrm{pacc}^{\mathrm{C}}\right)$ have also been shown to grow poorly at acidic $\mathrm{pH}$, whereas $P A C C$ loss-of-function mutants $\left(\mathrm{pacc}^{+/-}\right)$have been shown to grow poorly at alkaline $\mathrm{pH}$ (Penalva and Arst, 2004). Usually, PacC binds to the recognition site GCCAAG of the pH responsive genes (Espeso et al., 1997; Tilburn et al., 1995). The location of the PacC recognition sites upstream of the initiation codon in a PACC gene suggests that the expression of PACC is auto-regulated (Tilburn et al., 1995).

Studies of PacC show it has a DNA-binding domain containing three zinc fingers (Mingot et al., 1999; Tilburn et al., 1995), with a nuclear localization signal located in zinc finger 3 (Fernandez-Martinez et al., 2003; Mingot et al., 2001). In Aspergillus nidulans, PacC is reported to be activated by a two-step protease cleavage process (Diez et al., 2002; Mingot et al., 1999; Tilburn et al., 1995). Through the $\mathrm{pH}$ signaling pathway, PalA is bound to the full length $\mathrm{PacC}^{72}$, which may recruit the signaling protease $\mathrm{PalB}$ to cleave $\mathrm{PacC}^{72}$ at the signaling protease box, producing $\mathrm{PacC}^{53}$ (Vincent et al., 2003). PacC ${ }^{53}$ can then be cleaved by the processing protease, yielding the functional form $\mathrm{PacC}^{27}$, which is the predominant form found in the nucleus (Espeso and Arst, 2000; Fernandez-Martinez et al., 2003; Mingot et al., 2001). Constitutively active mutants can be constructed by truncation to remove the $\mathrm{C}$ terminus downstream of the signaling protease box, whereas loss-of-function mutations can be constructed by truncation before the processing protease box (Penalva and Arst, 2004).

Genes regulated by PacC mainly include those encoding transporters, such as the sodium pump gene ENAl and genes for siderophore transport (Caracuel et al., 2003a; Eisendle et al., 2004), those encoding permeases, such as the $\gamma$-aminobutyrate (GABA) permease-encoding gene GABA (Espeso and Arst, 2000), those encoding secreted enzymes, such as the acid phosphatase gene $P A C A$, the alkaline phosphatase gene $P A C D$, the alkaline protease gene PRTA, and the xylanase genes $X L N A$ and $X L N B$ (MacCabe et al., 1998; Tilburn et al., 1995), and those involved in the synthesis of exported metabolites such as the isopenicillin $\mathrm{N}$ synthase gene IPNA (Espeso and Penalva, 1996). In Saccharomyces cerevisiae, the transcription factor genes $N R G 1$ and SMP1 have also been found to be targeted by the PacC ortholog, Rim101, which binds to the promoters of $N R G 1$ and SMPI to repress their expression (Lamb and Mitchell, 
2003). In S. cerevisiae, deletion of RIM101 decreases invasive growth (Li and Mitchell, 1997). In Candida albicans, deletion of RIM101 represses filamentation at alkaline $\mathrm{pH}$ (Ramon et al., 1999), and constitutive mutation of RIM101 by-passes the $\mathrm{pH}$ restrictions on filamentation (El Barkani et al., 2000). Many cell wall proteins also are regulated by Rim101 in $C$. albicans, including the 1,3- $\beta$-glucanosyltransferase genes, $P H R 1$ and $P H R 2$ (Muhlschlegel and Fonzi, 1997; Ramon and Fonzi, 2003; Saporito-Irwin et al., 1995), and hypha-specific genes, $H W P 1, R B T 1$ and RBRI (Lotz et al., 2004). Interestingly, PacC is also known to be involved in fungal virulence. For example, when certain A. nidulans mutation strains were examined in a neutropenic murine model of pulmonary aspergillosis, pacc lossof-function mutants were found to grow less and show less penetration of the lungs than the wild-type (Bignell et al., 2005). In contrast, constitutive $\mathrm{pacc}^{c}$ strains were found to increase the mortality of mice and to produce more lung penetration. These results demonstrate that PacC plays an important role in aspergillosis pneumonia pathogenesis. In addition, the $C$. albicans rim101 $\Delta$ strain is known to be less virulent in a mouse model, less infectious to kidneys, and less infectious to endothelia cells (Davis et al., 2000a). However, in Fusarium oxysporum, the PACC loss-of-function mutation increased virulence and the PACC constitutive mutation decreased virulence in the infection of tomato roots (Caracuel et al., 2003b). Apparently the regulation of virulence by $\mathrm{PacC}$ is diverse among fungal strains growing in different conditions.

To investigate the regulation of $P A C C$, with respect to the growth of $W$. dermatitidis under different $\mathrm{pH}$ conditions, the $P A C C$ gene was cloned, characterized, and mutated, and the resulting mutants were then studied.

\section{MATERIALS AND METHODS}

\section{Strains, culture conditions and microscopy}

The well-characterized Wangiella dermatitidis strain 8656 (ATCC34100 [Exophiala dermatitidis CBS 525.76]) was the wild-type strain used in this study (Szaniszlo, 2002). The E. coli strain DH10B was used for the W. dermatitidis partial genomic library construction and the strain used for cloning was XL-1-blue. Routine culture of $W$. dermatitidis was on YPD agar (YPDA) and in YPD broth (YPDB) as described previously (Liu et al., 2004; Wang and Szaniszlo, 2007). To evaluate growth of $W$. dermatitidis cultured at different $\mathrm{pH}$, YPDA containing $100 \mathrm{mM}$ HEPES was titrated to $\mathrm{pH} 8$ with $\mathrm{NaOH}$, and to $\mathrm{pH} 4.5, \mathrm{pH} 3.5$, and $\mathrm{pH}$ 2.5 with $\mathrm{HCl}$. For the induction of sclerotic forms, $W$. dermatitidis was grown in modified Czapek Dox broth [MCDB; 3.5\% Czapek Dox, $0.1 \%$ yeast extract, $\mathrm{pH}$ adjusted with $\mathrm{HCl}$ (Wang and Szaniszlo, 2000)]. For the induction of the filamentous growth, W. dermatitidis was grown on potato dextrose agar (PDA; Difco Scientific, Detroit, Mich.) as described previously (Wang and Szaniszlo, 2007). For slide cultures, a thin square of PDA agar was placed on a slide and then inoculated on each side before being overlaid with a cover slip and incubated over water in a closed Petri dish. Microscopic pictures were taken with a Leica DFC camera and a Leica DMLB upright light microscope.

\section{Degenerate PCR}

To design degenerate PCR primers, the amino acid sequences of PacC family members from 10 filamentous fungi (A. nidulans, A. parasiticus, A. oryzae, A. niger, Penicillium chrysogenum, Sclerotinia sclerotiorum, Acremonium chrysogenum, Gibberella moniliformis, Gibberella fujikuroi, F. oxysporum) were aligned to find the conserved regions. Degenerate primers were derived and synthesized based on their conserved zinc finger regions with sequences: WPF1, CAYGTIGGIMGIAARWSXACXAAYAA and WPR1: ISWRTCRTCIGCRTGXGTYTTXACRTG ( $\mathrm{Y}=\mathrm{C}+\mathrm{T}, \mathrm{M}=\mathrm{A}+\mathrm{C}, \mathrm{R}=\mathrm{A}+\mathrm{G}, \mathrm{W}=\mathrm{A}+\mathrm{T}, \mathrm{S}=\mathrm{C}+\mathrm{G}$, $\mathrm{X}=\mathrm{A}+\mathrm{T}+\mathrm{C}+\mathrm{G})$. $\mathrm{PCR}$ amplifications were carried out with $2 \mu \mathrm{M}$ of each primer, $0.5 \mathrm{mM}$ dNTP, 
$0.5 \mu \mathrm{g}$ genomic DNA and $0.05 \mathrm{U} / \mu 1 \mathrm{Taq}$ polymerase mixed in $1.5 \mathrm{mM} \mathrm{Mg}^{++}, 50 \mathrm{mM} \mathrm{KCl}, 10$ $\mathrm{mM}$ Tris- $\mathrm{HCl}\left(\mathrm{pH}\right.$ 9) buffer. The PCR reaction conditions were as follows: $5 \mathrm{~min}$ at $94^{\circ} \mathrm{C}$ for premelting; 50 cycles of $1 \mathrm{~min}$ at $94^{\circ} \mathrm{C}$ for denaturation, $1 \mathrm{~min}$ at $55^{\circ} \mathrm{C}$ for annealing, and 1 $\min$ at $72^{\circ} \mathrm{C}$ for extension; $7 \mathrm{~min}$ at $72^{\circ} \mathrm{C}$ for completion of the extension. The resulting PCR products were then cloned into pGEM-T easy vector (Promega, Madison, Wis.) and sequenced. The sequencing showed that plasmid pT-WdPACC204 contained a 204-bp-amplified sequence corresponding to the zinc finger regions of the PacC proteins.

\section{Construction and screening of a $\boldsymbol{W}$. dermatitidis partial genomic library}

Southern analysis of the genomic DNA was carried out by digestion with different restriction enzymes as described previously (Wang and Szaniszlo, 2007). After a W. dermatitidis cosmid genomic library (Feng et al., 2001) was screened without success using the 204-bp sequence as a probe, a partial genomic library was constructed for isolating the full-length gene. Because Southern analysis showed that $a X h o I$ fragment containing the $P A C C$ gene was about $6 \mathrm{~kb}$, genomic DNA was first digested with $X h o I$ and then after electrophoresis, an $\sim 6 \mathrm{~kb}$ fragment was cut from the gel, purified by using the QIAquick gel extraction kit (Qiagen, Valencia, Calif.) and finally ligated into the $E$. coli vector pBSKS that had been previously digested with $X h o I$ and dephosphorylated with calf intestine alkaline phosphotase (CIAP, Promega). A clone containing the PACC sequence was then successfully obtained by screening more than $10^{4}$ colonies by hybridization using the 204-bp sequence as a probe. Sequencing was carried out with gene-specific primers using big dye chemistries and capillary-based ABI 3130 and ABI 3739 DNA analyzers (Applied Biosystems, Foster City, Calif.) (Core Facility of the Institute of Cellular and Molecular Biology, University of Texas at Austin). The sequencing showed that a $5859 \mathrm{bp} \mathrm{W.} \mathrm{dermatitidis} \mathrm{sequence} \mathrm{was} \mathrm{inserted} \mathrm{in} \mathrm{the} \mathrm{XhoI} \mathrm{site} \mathrm{of} \mathrm{pBSKS.} \mathrm{This} \mathrm{plasmid}$ was named pBSKS-WP5859.

\section{RT-PCR}

To locate the positions of the introns, RNA was extracted with hot acidic phenol from $W$. dermatitidis cells grown in YPDB for $24 \mathrm{~h}$ at $37^{\circ} \mathrm{C}$ and treated with RQ1 RNase-Free DNase (Promega). RT-PCR was carried out with primers WP17F:

CTGCTCGAGATGTCTGAACTCGCCGAGACCAG, and WP18R:

TCGCTCGAGGCGTTTGCGAGCCTCATAATC, using the One-step RT-PCR kit (Qiagen). After the amplification products were cloned into pGEM-T easy vector (Promega) and sequenced, the cDNA sequence was aligned with the genomic DNA sequence to identify introns.

\section{PACC mutagenesis}

To create the $W$. dermatitidis PACC mutation strains by a one-step replacement method, fragments containing the $h p h$ selection marker (Liu et al., 2004) flanked by PACC 5' and 3' sequences were constructed. For the loss-of-function mutation, a 5 ' flanking sequence was amplified by PCR with primers WPF10: GGATCCCGAGTGTCAATTCAGCTGGA, and WPR10: CTACTGGTTATGGTGATGTTGACCA (the BamHI site that was introduced is underlined, and the stop codon is italicized). The products amplified were cloned into the pGEM-T easy vector (Promega) to produce plamid pT-WP1 for sequencing. For the constitutive mutation, a 5' flanking sequence was amplified by PCR with primers WPF11: GGATCCTCAGCTTCCCCAGATCATTC, and WPR11: CTAACGGCGACGCTCTTCCTGATCATA (the BamHI site that was introduced is underlined, and the stop codon is italicized). The amplified products were cloned to pGEM-T easy vector (Promega), to produce plasmid pT-WP2 for sequencing. After 0.5-kb BamHISall fragments were released from both pT-WP1 and pT-WP2, they were cloned into the pBCKS vector (Stratagene, La Jolla, Calif.), generating plasmids pBCKS-WP1 and pBCKS- 
WP2, respectively. After release of a 1.4-kb SalI fragment containing the $h p h$ marker from pCB1636 (Fungal Genetics Stock Center, University of Kansas Medical Center, Kansas City, Kans.), it was inserted into the SalI site of pBCKS-WP1 and pBCKS-WP2 to produce pBCKSWP3 and pBCKS-WP4, respectively. The 3' flanking sequence was amplified by PCR with primers WPF12: GAACAGAGGCGTGGAGGTTA, and WPR12:

GGTACCACGCGTACGACCCCTTACTA (the introduced KpnI site is underlined). The amplified products were cloned to pGEM-T easy vector (Promega) to produce plasmid pTWP3 for sequencing. A $0.5-\mathrm{kb}$ SalI-KpnI fragment was released from pT-WP3 and ligated into the XhoI-KpnI sites of pBCKS-WP3 and pBCKS-WP4 to produce pBCKS-WP5 and pBCKSWP6, respectively. After the 2.4-kb XbaI-KpnI fragments were released from pBCKS-WP5 and pBCKS-WP6, they were gel purified and used to transform yeast cells of the $W$. dermatitidis wild-type strain by electroporation (Wang and Szaniszlo, 2000; Zheng and Szaniszlo, 1999). Transformants were selected on YPDA containing $50 \mu \mathrm{g} / \mathrm{ml}$ hygromycin. PCR with primers WPF16: CATCGACCCTGCTCTTGCA and WPR16:

CGATGAGTCGCATGTTCTGAA were used to screen the transformants. The amplification products were analyzed by electrophoresis in a 3\% agarose gel together with a 2-log DNA marker (New England Biolabs, Ipswich, Mass.) as a size reference. Southern analysis of genomic DNA digested with SalI and hybridized with the 204-bp PACC probe was used to confirm the mutants.

\section{Analysis of $W$. dermatitidis growth by spot assays}

The spot assays were carried out as described previously (Wang and Szaniszlo, 2000) with logphase yeast cells of $W$. dermatitidis cultured in YPDB at $25^{\circ} \mathrm{C}$. After 10 -fold serial dilution, cells in $5 \mu \mathrm{l}$ were spotted with a micropipette onto agar media, and then incubated at $25^{\circ} \mathrm{C}$ and $37^{\circ} \mathrm{C}$.

\section{Northern analysis}

For the Northern analysis, log-phase yeast cells of $W$. dermatitidis cultured in YPDB at $25^{\circ} \mathrm{C}$ were washed and then used to inoculate $\mathrm{pH} 7$ and $\mathrm{pH} 3 \mathrm{MCDB}$ at $10^{6}$ cells $/ \mathrm{ml}$, and $\mathrm{pH} 2.5$ MCDB at $10^{7}$ cells $/ \mathrm{ml}$. After cells were cultured for several days with vigorous shaking at $25^{\circ}$ $\mathrm{C}$, the $\mathrm{pH}$ was measured to insure its constancy. Total RNA was isolated with the RNeasy kit (Qiagen). The concentration of RNA was determined using a NanoDrop ND-1000

Spectrophotometer (NanoDrop Technologies, Wilmington, Del.). RNA electrophoresis was in a $1 \%$ agarose gel containing $2 \mathrm{M}$ formaldehyde, and a 0.24-9.5 kb RNA ladder (Invitrogen, Carlsbad, Calif.) was run simultaneously as a size marker. After transfer of RNA from the gel to the nylon membrane, transfer efficiency was checked. For the $P A C C$ probe, the 204-bp $P A C C$ fragment from $p T$-WdPACC204 was used. For the $C H S 1$ probe, a fragment was amplified by PCR with specific primers (Wang et al., 2002). After Northern hybridization, radioactive signals were detected by exposure to a phosphoimager screen, which was then scanned with a Molecular Imager FX Pro Plus multiimager system (Bio-Rad, Hercules, Calif.).

\section{Nucleotide sequence accession number}

The sequence of the W. dermatitidis PACC gene was submitted to the GenBank database. The accession number is EU367502.

\section{RESULTS}

\section{Isolation and sequence characterization of the W. dermatitidis PACC gene}

To clone the W. dermatitidis PACC gene, ten PacC family members of filamentous fungi were aligned, and then degenerate primers were designed based on the nucleotide sequences of their conserved zinc finger DNA-binding domains. A PCR product amplified with the degenerate 
primers was then cloned, which was shown by sequence analysis to encode a protein fragment corresponding to that of a PacC zinc finger domain. Using this fragment as a probe, Southern analysis of genomic DNA digested with different restriction enzymes indicated that PACC existed as a single copy in the $W$. dermatitidis genome (data not shown).

Because a PACC hybridization signal was not found in a screen of a $W$. dermatitidis cosmid genomic library, a $W$. dermatitidis subgenomic library was constructed and screened for its isolation. Detection and sequencing of an isolated plasmid revealed that an inserted $W$.

dermatitidis sequence was 5,958 bp, and contained the PACC ORF consisting of bp 2,855 to 4,912. Analysis of the upstream sequence using the MatInspector software

(www.genomatix.de) identified three important consensus PacC binding sites at $-796 \mathrm{bp},-949$ bp and -1122 bp upstream of the ORF start codon, suggesting that these elements are required in $W$. dermatitidis for the regulation of PACC expression. The binding site detected at -796 bp was on the sense strand, and the other two binding sites were on the anti-sense strand. Comparison of the cDNA sequence obtained by RT-PCR and the genomic DNA sequence revealed the presence of two introns of $60 \mathrm{bp}$ and $57 \mathrm{bp}$. The first intron was between the coding sequence for Y108 and E109 in the first zinc finger, whereas the second intron, which does not introduce stop codons or frame shifts, was located between the coding sequence for S252 and S253, and is about 30 residues upstream of the conserved processing protease cleavage site. Both introns began with GT at their 5' ends and end with AG at their 3' ends, and therefore conformed to the "GT-AG" rule.

Analysis of $W$. dermatitidis PACC ORF showed that it encoded a putative protein of 646 aa (Figure 1) with a theoretical isoelectric point (pI) of 5.83 and a molecular weight $(\mathrm{Mw})$ of 69.8 $\mathrm{kDa}$. Protein structure predictions showed that the predicted PacC protein contained three $\mathrm{C} 2 \mathrm{H} 2$-type zinc fingers for DNA binding (residues 90 to 115 , residues 126 to 150 and residues 156 to 178, based on Pfam database), had Asn- (12-27), Ala- (32-47) and Gln- (56-78) rich regions before the zinc finger motifs, and was an $\alpha$-helix-rich protein. BLASTP

(www.ncbi.nlm.nih.gov/BLAST) analysis indicated that the PacC protein of W. dermatitidis was most similar to the PacC proteins of other Ascomycota conidiogenous fungi. Like other PacC family members, it also had a processing protease cleavage site (278-280) and a signaling protease box (484-510).

\section{The PACC gene is more expressed at neutral-alkaline $\mathrm{pH}$ than at acidic $\mathrm{pH}$}

Northern analysis of RNA from wild-type cells cultured for $24 \mathrm{~h}$ in $\mathrm{pH} 7$ and $\mathrm{pH} 3 \mathrm{MCDB}$ at $25^{\circ} \mathrm{C}$ showed that $P A C C$ was more highly expressed at $\mathrm{pH} 7$ than at $\mathrm{pH} 3$ (Figure 2). Thus, $P A C C$ RNA expression was $\mathrm{pH}$ regulated, suggesting that its encoded protein, plays an important role in the regulation of $W$. dermatitidis growth at different $\mathrm{pH}$ conditions.

\section{The loss-of function and constitutive PACC mutants of $W$. dermatitidis were constructed by one-step replacements}

Because the W. dermatitidis PacC protein structure is similar to that of the A. nidulans PacC structure, loss-of-function $\left(\mathrm{pacc}^{+/-}\right)$and constitutive $\left(\mathrm{pacc}^{c}\right)$ mutant forms of PACC were derived to be similar to those of that fungus (Tilburn et al., 1995). In the W. dermatitidis $\mathrm{pacc}^{+/-}$mutant, PacC was truncated after residue Q243 at about 40 residues upstream of the conserved processing protease cleavage site, whereas in the pacc $^{c}$ mutant, $\mathrm{PacC}$ was truncated after residue R501 in the conserved signaling protease box (Figure 3A, B). Initial screening of the hygromycin resistant, putative $\mathrm{pacc}^{+/-}$and $\mathrm{pacc}^{c}$ mutants was by PCR diagnosis of their genomic DNA with specific primers. Whereas the wild type showed a 100-bp PCR-amplified band, the mutants selected for further analysis were devoid of this band (data not shown). Among the putative $\mathrm{pacc}^{+/-}$strains, three of 39 transformants had the desired deletion and all three of these particular transformants produced smaller colonies, whereas among the putative 
$\operatorname{pacc}^{c}$ transformants, approximately one out of six had the deletion and none exhibited an abnormal phenotype on the YPDA-hygromycin medium compared to the other transformants. Further analysis of the $\mathrm{pacc}^{+/-}$and $\mathrm{pacc}^{c}$ strains by Southern hybridization of SalI digested genomic DNA, using the 204-bp PACC fragment in the DNA binding domain as a probe, showed that unlike the wild type, which showed a 7-kb band, all the putative acc $^{+/-}$strains had a $0.9-\mathrm{kb}$ band and all the putative pacc $^{c}$ strains had a $1.7-\mathrm{kb}$ band, consistent with designs (Figure 3C). Because preliminary studies of all the $\mathrm{pacc}^{+/-}$strains and all the $\mathrm{pacc}^{c}$ strains had identical phenotypes, the detailed comparisons with the wild type described below were only with the $\mathrm{pacc}^{+/-}-1$ and $\mathrm{pacc}^{\mathrm{c}-1}$ strains. Northern analysis of PACC RNA showed that in the pacc $^{+/-}-1$ mutant, the size was smaller and the amount was about 2-fold lower than that in the wild-type at $\mathrm{pH} 7.4$; whereas in the pacc $^{c}-1$ mutant, the sizes were $3 \mathrm{~kb}, 2.4 \mathrm{~kb}, 1.8 \mathrm{~kb}$ and 1.4 $\mathrm{kb}$, and the total amount was more than that in the wild-type at $\mathrm{pH} 7.4$ and $\mathrm{pH} 2.5$ (Figure 3D). The apparently diverse sizes of $P A C C$ RNA in the pacc $^{c}-1$ mutant suggested that its expression was influenced by different transcription start sites, alternative splicing or RNA stability. Retesting of the $\mathrm{pacc}^{+/-}-1$ mutant on YPDA in the absence of hygromycin confirmed that this loss-of-function mutation strain also produced smaller colonies when hygromycin was not present, whereas the amount of growth of the pacc ${ }^{-}-1$ mutant was similar to that of the wild type, although somewhat darker (Figure 4).

\section{$P A C C$ influences the growth of $W$. dermatitidis when cultured under different $\mathrm{pH}$ conditions on YPDA}

To investigate the effects of $\mathrm{pH}$ on the growth of the wild type and mutants, cells were diluted and spotted on YPDA titrated to $\mathrm{pH} 8, \mathrm{pH} 4.5, \mathrm{pH} 3.5$ and $\mathrm{pH} 2.5$, and cultured at $25^{\circ} \mathrm{C}$ and $37^{\circ} \mathrm{C}$ for three days (Figure 5). In general, the wild type grew somewhat better on YPDA adjusted to $\mathrm{pH} 8, \mathrm{pH} 4.5$ and $\mathrm{pH} 3.5$ at $37^{\circ} \mathrm{C}$ than it did at $25^{\circ} \mathrm{C}$, and grew less on YPDA adjusted to $\mathrm{pH} 2.5$ at $37^{\circ} \mathrm{C}$ than it did at $25^{\circ} \mathrm{C}$. At $25^{\circ} \mathrm{C}$, the growth of the wild type was also reduced on YPDA at $\mathrm{pH} 8, \mathrm{pH} 3.5$ and $\mathrm{pH} 2.5$ compared with that produced at $\mathrm{pH} 4.5$. In contrast, at $37^{\circ} \mathrm{C}$, the growth of the wild type was only reduced to any great extent on YPDA at $\mathrm{pH} 2.5$, compared with the growth it produced at $\mathrm{pH} 8, \mathrm{pH} 4.5$ and $\mathrm{pH} 3.5$. At both temperatures, the $\mathrm{pacc}^{+/-}-1$ mutant grew poorer on YPDA at all the $\mathrm{pH}$ levels tested compared to the wild type, with the exception that the growth of the mutant and wild type was equivalent at $37^{\circ} \mathrm{C}$ and at $\mathrm{pH} 2.5$. In addition, the growth defect of $\mathrm{pacc}^{+/-}-1$ also appeared more pronounced at $25^{\circ} \mathrm{C}$ than at $37^{\circ} \mathrm{C}$. At both temperatures, the growth of pacc ${ }^{c}-1$ mutant was less at $\mathrm{pH} 3.5$ and $\mathrm{pH} 2.5$ than at $\mathrm{pH} 8$ and $\mathrm{pH} 4.5$, compared with the wild type. These results indicated that PacC played a role in the regulation of the yeast reproductive growth of $W$. dermatitidis under the different $\mathrm{pH}$ conditions tested.

\section{The PACC constitutive mutation affects $W$. dermatitidis growth and $C H S 1$ expression at acidic $\mathrm{pH}$}

In $\mathrm{pH} 2.5 \mathrm{MCDB}$ at $25^{\circ} \mathrm{C}, \mathrm{W}$. dermatitidis is induced to form sclerotic morphotypes (Wang and Szaniszlo, 2000). To investigate the effects of the PACC mutations on the induction of these morphotypes, cells were cultured in $\mathrm{pH}$ 2.5 MCDB (Figure 6A). As expected, after two days of incubation, wild-type cells had begun to produce sclerotic cells and some planate cells. Interestingly, the $\mathrm{pacc}^{+/-}-1$ loss-of-function mutation did not affect the conversion to a sclerotic morphotype. In contrast the $\mathrm{pacc}^{c}-1$ constitutive mutation repressed the conversion of obviously enlarged sclerotic cells to planate cells and sclerotic bodies. In fact, all of the

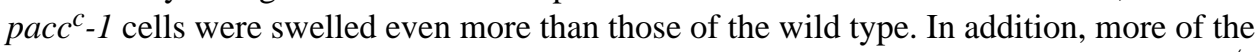
pacc $^{c}-1$ cells contained large vacuoles when compared with the wild type and the $\mathrm{pacc}^{+/-}-1$ cells (data not shown). In $\mathrm{pH} 4.5 \mathrm{MCDB}$, however, the wild type and the $p^{2} c^{c}-1$ and $\mathrm{pacc}^{+/-}-1$ mutants all grew comparably as budding yeast cells (data not shown). 
Because we observed that the $\mathrm{pacc}^{c}-1$ mutant was somewhat darker than the wild-type strain, a situation often found previously to be related to cell wall integrity defects in $W$.

dermatitidis (Liu et al., 2004; Wang et al., 1999; Zheng et al., 2006), we investigated whether the product of $P A C C$ might affect the expression of any of its previously studied chitin synthase genes. Northern analysis showed that only the expression of its class II chitin synthase gene was obviously affected, as documented by a decreased level of CHS1 RNA in the pacc ${ }^{c}-1$ mutant compared with that of the wild type and the $\mathrm{pacc}^{+/-}-1$ mutant when each was grown identically at $\mathrm{pH} 2.5$ (Figure 6B). Surprisingly, CHS1 was the only chitin synthase gene that was detected to be significantly affected by $P A C C$ mutation under this or the other conditions tested (data not shown).

\section{The pacc $^{+/-}-1$ mutant is most sensitive to $\mathrm{Na}^{+}$stress}

Because PacC proteins are often involved in the regulation of $\mathrm{Na}^{+}$stress, the effects of $\mathrm{Na}^{+}$ stress on the wild type and the PACC mutation strains spotted on YPDA (pH 4.5) and YPDA supplemented with $0.4 \mathrm{M} \mathrm{NaCl}$ and cultured at $25^{\circ} \mathrm{C}$ and $37^{\circ} \mathrm{C}$ were evaluated (Figure 7). The growth of the wild type was moderately reduced on YPDA supplemented with $0.4 \mathrm{M} \mathrm{NaCl}$ at both temperatures. Although the growth pattern of the $p a c c^{c}-1$ mutant was similar to that of the wild type on both media at both temperatures, the growth of the $\mathrm{pacc}^{+/-}-1$ mutant was severely reduced on the YPDA+0.4 $\mathrm{M} \mathrm{NaCl}$ when cultured identically. In addition, the pacc $^{+/-}-1$ mutant grew even less on the YPDA $+0.4 \mathrm{M} \mathrm{NaCl}$ at $37^{\circ} \mathrm{C}$ than at $25^{\circ} \mathrm{C}$, indicating the sensitivity of $\mathrm{pacc}^{+/-}-1$ to $0.4 \mathrm{M} \mathrm{NaCl}$ was enhanced at $37^{\circ} \mathrm{C}$.

\section{PacC regulates yeast-hyphal transitions in $W$. dermatitidis}

In C. albicans and S. cerevisiae, the PacC ortholog, Rim101, is involved in the dimorphic switching between yeast and hyphae or pseudohyphae and deletion of RIM101 represses filamentous growth (El Barkani et al., 2000; Li and Mitchell, 1997; Ramon et al., 1999). Therefore, we investigated whether PacC also regulates the yeast-hyphal transitions in $W$. dermatitidis. For this yeast cells of each strain were spread on a block of PDA (pH 5.6) and incubated at $25^{\circ} \mathrm{C}$. Under these conditions, the a $^{+/-}-1$ mutant produced only a few filaments at the edges of colonies, even after 7 days of incubation, whereas the wild type and pacc ${ }^{c}-1$ strain produced many filaments at their edges in only 4 days (Figure 8). Moreover, these PDA slide cultures were prepared in a way that allowed aerial hyphae and conidiophores, if produced, to grow horizontally out of the agar into the air between a slide and a cover glass. At $25^{\circ} \mathrm{C}$, many aerial hyphae and conidia were produced by the wild type and the acc $^{+/-}-1$ and pacc $^{c}-1$ mutants (Figure 9). These results thus suggested that PacC positively regulated filamentous growth in $W$. dermatitidis, but did not positively regulate its conidiogenesis if hyphae were produced.

\section{DISCUSSION}

$W$. dermatitidis can grow in a wide range of $\mathrm{pH}$ conditions. At $\mathrm{pH} 3$ and above, $W$. dermatitidis in most rich media grows reproductively as budding yeast and in most less rich, nitrogen-deficient media as a filamentous mold (Szaniszlo, 2002; Szaniszlo et al., 1976). However, if the $\mathrm{pH}$ of the rich culture media is 2.5 or if less acidic media are calcium-deficient, then this polymorphic fungus grows in a variety of non-polarized sclerotic forms, and its polarized yeast and hyphal growth is repressed (Karuppayil and Szaniszlo, 1997; Szaniszlo, 2002; Szaniszlo et al., 1976). As an initial step in the study of the regulation of growth in $W$. dermatitidis cultured under different $\mathrm{pH}$ conditions, the $P A C C$ gene, which encodes an important $\mathrm{pH}$ pathway transcription factor in other fungi, was cloned and the effects of its mutation studied. 
Comparison of the deduced protein sequence of the W. dermatitidis PacC showed that it was much conserved among PacC family members (Figure 1). The most conservation was in its second and third zinc fingers, consistent with the situation in A. nidulans, in which those zinc fingers have been found to make direct interactions with DNA and to be involved in nuclear localization (Espeso et al., 1997;Fernandez-Martinez et al., 2003;Mingot et al., 2001;Tilburn et al., 1995). In addition, the position of the first intron in the PACC gene of W. dermatitidis was also very conserved (Caracuel et al., 2003b;Flaherty et al., 2003;MacCabe et al., 1996;Rollins and Dickman, 2001;Schmitt et al., 2001;Suarez and Penalva, 1996;Tilburn et al., 1995). However, the position of the second intron was unique and suggestive of alternative splicing, because the presence of the second intron does not introduce a stop codon or a frame shift. In addition, and as predicted by MatInspector software, three PacC binding sites were found to exist between -796 bp and -1122 bp upstream of the PACC translation start codon, which suggests that $P A C C$ expression in $W$. dermatitidis is auto-regulated by its encoded protein. However, most important to the goal of this particular study was our finding by Northern analysis that the RNA expression of the PACC gene in the wild-type strain of $W$. dermatitidis was notably higher at neutral-alkaline $\mathrm{pH}$ than it was at acidic $\mathrm{pH}$ (Figure 2), suggesting that $P A C C$ is a marker gene of $\mathrm{pH}$ signaling in this pathogenic fungus. This in turn implies that its product, $\mathrm{PacC}$, might be crucial for maintaining the growth of $W$. dermatitidis at different $\mathrm{pH}$ conditions in the human body.

Loss-of-function $\left(\mathrm{pacc}^{+/-}\right)$and constitutive $\left(\mathrm{pacc}^{c}\right)$ strains with mutant forms of PACC were derived to study its function in $W$. dermatitidis. The $\mathrm{pacc}^{+/-}-1$ loss-of-function strain grew less than the wild type under normal conditions at both $25^{\circ} \mathrm{C}$ and $37^{\circ} \mathrm{C}$ (Figure 4), suggesting that the genes of $W$. dermatitidis involved in growth at normal temperatures are activated by PacC. This finding contrasts with those derived with S. cerevisiae, C. albicans and Ustilago maydis, in which the deletion of RIM101 does not affect growth rate at normal temperatures (Arechiga-Carvajal and Ruiz-Herrera, 2005;Davis et al., 2000b;Li and Mitchell, 1997), but is in agreement that found with A. nidulans where the PACC null deletion mutant is decreased in its rate of growth at the normal temperature (Tilburn et al., 1995). Interestingly, we also found that pacc $^{-}-1$ was somewhat blacker than the wild type and that $\mathrm{pacc}^{+-}-1$ was somewhat less dark than the wild type on YPDA (Figure 4), suggesting that PacC may be involved in the activation of melanin biosynthesis in $W$. dermatitidis. Our subsequent finding that the growth patterns of the PACC mutation strains were tightly $\mathrm{pH}$ related provided further supporting evidence for our ultimate conclusion that PacC plays critical regulatory roles in the responses of $W$. dermatitidis to $\mathrm{pH}$.

Of the five chitin synthase genes of $W$. dermatitidis analyzed in this study, only the RNA level of its CHSIgene, which encodes a class II chitin synthase, was clearly decreased at $\mathrm{pH} 2.5$ in the $\operatorname{pacc}^{\mathrm{c}}-1$ strain compared with that of the wild type and the $\mathrm{pacc}^{+/-}-1$ strains (Figure 6B). Because the chs $1 \Delta$ mutant also grew poorly at $\mathrm{pH} 2.5$ (data not shown), and is darker (Zheng et al., 2006), the decreased $C H S I$ expression may have a relationship with the poor growth of pacc $^{c}-1$ at this condition. However, it appears that $C H S 1$ RNA expression was not obviously regulated by $\mathrm{pH} 2.5$ and $\mathrm{pH} 7$, and also was not obviously regulated by the PACC loss-offunction mutation at $\mathrm{pH} 7$ (data not shown). Also the promoter of $C H S 1$ was not found to contain a PacC consensus binding site. Thus the expression of $\mathrm{CHS} 1$ in W. dermatitidis may be only indirectly regulated by its $\mathrm{PacC}$ protein.

The $\mathrm{pacc}^{+/-}-1$ mutant was very sensitive to $0.4 \mathrm{M} \mathrm{Na}^{+}$on YPDA (Figure 7), which suggests that $\mathrm{PacC}$ may regulate a plasma membrane $\mathrm{Na}^{+}$-ATPase pump in $W$. dermatitidis, a hypothesis consistent with the finding that the sodium pump gene ENAl is activated by PacC in F. oxysporum and by Rim101 in S. cerevisiae (Caracuel et al., 2003a;Lamb et al., 2001). Sodium dodecyl sulfate (SDS), a cell wall perturbation reagent, and caffeine, a drug that affects parts of a potential cell wall integrity pathway, are reported to inhibit the growth of the $S$. cerevisiae 
rim101 $\Delta$ mutant (Castrejon et al., 2006). In contrast, the treatments of $W$. dermatitidis in spot assays with YPDA supplemented with $0.002 \%$ SDS and with YPDA supplemented with $4 \mathrm{mM}$ caffeine did not reduce the growth of the $\mathrm{pacc}^{+/-}-1$ mutant to any greater extent than they did with the wild type at $25^{\circ} \mathrm{C}$ and $37^{\circ} \mathrm{C}$ (data not shown). These results suggested that the pacc $^{+/-}-1$ mutant was hypersensitive to $0.4 \mathrm{M} \mathrm{Na}^{+}$but not very sensitive to $0.002 \%$ SDS and $4 \mathrm{mM}$ caffeine.

It is important to note that in yeast species, such as $S$. cerevisiae and $C$. albicans, the PacC homolog Rim101 was found to be involved in yeast-hyphal transitions. Here we show that in $W$. dermatitidis, a filamentous, conidiogenous mold, capable of polymorphic vegetative growth, $\mathrm{PacC}$ also regulates yeast-hyphal transitions. In this respect, we found that the $\mathrm{pacc}^{+/-}-1$ mutant strain was largely decreased in filamentous growth on PDA at $25^{\circ} \mathrm{C}$ (Figure 8 ), but conidiation still occurred (Figure 9), suggesting that the conidiation genes were not repressed. This result differs from our previous findings that the putative transcription factors StuA and Tup1 of $W$. dermatitidis, which both have orthologs known to function in conidiogenesis in A. nidulans, are involved in activating the regulation of both yeast-hyphal transition and conidiogenesis in W. dermatitidis (Liu et al., 2008; Wang and Szaniszlo, 2007). In addition, both the stua $\Delta 1 A$ and tup $1 \Delta-1$ strains in $W$. dermatitidis produced convoluted colony surface growth on YPDA at $37^{\circ} \mathrm{C}$ (Liu et al., 2008; Wang and Szaniszlo, 2007), whereas $\mathrm{pacc}^{+/-}-1$ did not produce this colony phenotype (data not shown). Finally the overexpression of StuA in W. dermatitidis strongly repressed filamentous growth on PDA at $25^{\circ} \mathrm{C}$ and $37^{\circ} \mathrm{C}$ and convoluted growth on YPDA at $37^{\circ} \mathrm{C}$ (Wang and Szaniszlo, 2007), whereas constitutive expression of PacC slightly activated filamentous growth on PDA at $25^{\circ} \mathrm{C}$ and $37^{\circ} \mathrm{C}$ and convoluted growth on YPDA at $37^{\circ} \mathrm{C}$ (data not shown). These results suggest that PacC, StuA and Tup 1 in $W$. dermatitidis may have common regulatory targets, and also have their own specific regulatory targets. Further exploration of these possibilities is therefore warranted.

\section{ACKNOWLEDGEMENTS}

This research was supported by a grant to P.J.S. from the National Institute of Allergy and Infectious Disease (AI33049).

\section{REFERENCES}

Abramczyk D, Park C, Szaniszlo PJ. Cytolocalization of the class V chitin synthase in the yeast, hyphal and sclerotic morphotypes of Wangiella (Exophiala) dermatitidis. Fungal Gen. Biol 2009;46:28-41.

Arechiga-Carvajal ET, Ruiz-Herrera J. The RIM101/pacC homologue from the basidiomycete Ustilago maydis is functional in multiple pH-sensitive phenomena. Eukaryot. Cell 2005;4:999-1008. [PubMed: 15947192]

Bignell E, Negrete-Urtasun S, Calcagno AM, Haynes K, Arst HN Jr, Rogers T. The Aspergillus pHresponsive transcription factor PacC regulates virulence. Mol. Microbiol 2005;55:1072-1084. [PubMed: 15686555]

Caracuel Z, Casanova C, Roncero MI, Di Pietro A, Ramos J. pH response transcription factor PacC controls salt stress tolerance and expression of the P-Type $\mathrm{Na}^{+}$-ATPase Ena1 in Fusarium oxysporum. Eukaryot. Cell 2003a;2:1246-1252. [PubMed: 14665459]

Caracuel Z, Roncero MI, Espeso EA, Gonzalez-Verdejo CI, Garcia-Maceira FI, Di Pietro A. The pH signalling transcription factor PacC controls virulence in the plant pathogen Fusarium oxysporum. Mol. Microbiol 2003b;48:765-779. [PubMed: 12694620]

Castrejon F, Gomez A, Sanz M, Duran A, Roncero C. The RIM101 pathway contributes to yeast cell wall assembly and its function becomes essential in the absence of mitogen-activated protein kinase Slt2p. Eukaryot. Cell 2006;5:507-517. [PubMed: 16524906]

Davis D, Edwards JE Jr, Mitchell AP, Ibrahim AS. Candida albicans RIM101 pH response pathway is required for host-pathogen interactions. Infect. Immun 2000a;68:5953-5959. [PubMed: 10992507] 
Davis D, Wilson RB, Mitchell AP. RIM101-dependent and-independent pathways govern $\mathrm{pH}$ responses in Candida albicans Mol. Cell. Biol 2000b;20:971-978.

Diez E, Alvaro J, Espeso EA, Rainbow L, Suarez T, Tilburn J, Arst HN Jr, Penalva MA. Activation of the Aspergillus PacC zinc finger transcription factor requires two proteolytic steps. EMBO J 2002;21:1350-1359. [PubMed: 11889040]

Eisendle M, Oberegger H, Buttinger R, Illmer P, Haas H. Biosynthesis and uptake of siderophores is controlled by the PacC-mediated ambient-pH Regulatory system in Aspergillus nidulans. Eukaryot. Cell 2004;3:561-563. [PubMed: 15075286]

El Barkani A, Kurzai O, Fonzi WA, Ramon A, Porta A, Frosch M, Muhlschlegel FA. Dominant active alleles of RIM101 (PRR2) bypass the $\mathrm{pH}$ restriction on filamentation of Candida albicans. Mol. Cell. Biol 2000;20:4635-4647. [PubMed: 10848590]

Espeso EA, Arst HN Jr. On the mechanism by which alkaline $\mathrm{pH}$ prevents expression of an acid-expressed gene. Mol. Cell. Biol 2000;20:3355-3363. [PubMed: 10779325]

Espeso EA, Penalva MA. Three binding sites for the Aspergillus nidulans PacC zinc-finger transcription factor are necessary and sufficient for regulation by ambient $\mathrm{pH}$ of the isopenicillin $\mathrm{N}$ synthase gene promoter. J. Biol. Chem 1996;271:28825-28830. [PubMed: 8910527]

Espeso EA, Tilburn J, Sanchez-Pulido L, Brown CV, Valencia A, Arst HN Jr, Penalva MA. Specific DNA recognition by the Aspergillus nidulans three zinc finger transcription factor PacC. J. Mol. Biol 1997;274:466-480. [PubMed: 9417928]

Feng B, Wang X, Hauser M, Kaufmann S, Jentsch S, Haase G, Becker JM, Szaniszlo PJ. Molecular cloning and characterization of WdPKS1, a gene involved in dihydroxynaphthalene melanin biosynthesis and virulence in Wangiella (Exophiala) dermatitidis. Infect. Immun 2001;69:17811794. [PubMed: 11179356]

Fernandez-Martinez J, Brown CV, Diez E, Tilburn J, Arst HN Jr, Penalva MA, Espeso EA. Overlap of nuclear localisation signal and specific DNA-binding residues within the zinc finger domain of PacC. J. Mol. Biol 2003;334:667-684. [PubMed: 14636595]

Flaherty JE, Pirttila AM, Bluhm BH, Woloshuk CP. PAC1, a pH-regulatory gene from Fusarium verticillioides. Appl. Environ. Microbiol 2003;69:5222-5227. [PubMed: 12957906]

Geiser DM, Gueidan C, Miadlikowska J, Lutzoni F, Kauff F, Hofstetter V, Fraker E, Schoch CL, Tibell L, Untereiner WA, Aptroot A. Eurotiomycetes: Eurotiomycetidae and Chaetothyriomycetidae. Mycologia 2006;98:1053-1064. [PubMed: 17486980]

Karuppayil SM, Szaniszlo PJ. Importance of calcium to the regulation of polymorphism in Wangiella (Exophiala) dermatitidis. J. Med. Vet. Mycol 1997;35:379-388. [PubMed: 9467104]

Lamb TM, Mitchell AP. The transcription factor Rim101p governs ion tolerance and cell differentiation by direct repression of the regulatory genes NRG1 and SMP1 in Saccharomyces cerevisiae. Mol. Cell. Biol 2003;23:677-686. [PubMed: 12509465]

Lamb TM, Xu W, Diamond A, Mitchell AP. Alkaline response genes of Saccharomyces cerevisiae and their relationship to the RIM101 pathway. J. Biol. Chem 2001;276:1850-1856. [PubMed: 11050096]

Li W, Mitchell AP. Proteolytic activation of Rim1p, a positive regulator of yeast sporulation and invasive growth. Genetics 1997;145:63-73. [PubMed: 9017390]

Liu H, Abramczyk D, Cooper CR Jr, Zheng L, Park C, Szaniszlo PJ. Molecular cloning and characterization of $W d T U P 1$, a gene that encodes a potential transcriptional repressor important for yeast-hyphal transitions in Wangiella (Exophiala) dermatitidis. Fungal Genet. Biol 2008;45:646656. [PubMed: 18061494]

Liu H, Kauffman S, Becker JM, Szaniszlo PJ. Wangiella (Exophiala) dermatitidis WdChs5p, a class V chitin synthase, is essential for sustained cell growth at temperature of infection. Eukaryot. Cell 2004;3:40-51. [PubMed: 14871935]

Lotz H, Sohn K, Brunner H, Muhlschlegel FA, Rupp S. RBRl, a novel pH-regulated cell wall gene of Candida albicans, is repressed by RIM101 and activated by NRG1. Eukaryot. Cell 2004;3:776-784. [PubMed: 15189998]

MacCabe AP, Orejas M, Perez-Gonzalez JA, Ramon D. Opposite patterns of expression of two Aspergillus nidulans xylanase genes with respect to ambient pH. J. Bacteriol 1998;180:1331-1333. [PubMed: 9495775] 
MacCabe AP, Van den Hombergh JP, Tilburn J, Arst HN Jr, Visser J. Identification, cloning and analysis of the Aspergillus niger gene pacC, a wide domain regulatory gene responsive to ambient $\mathrm{pH}$. Mol. Gen. Genet 1996;250:367-374. [PubMed: 8602152]

Matsumoto T, Ajello L, Matsuda T, Szaniszlo PJ, Walsh TJ. Developments in hyalohyphomycosis and phaeohyphomycosis. J. Med. Vet. Mycol 1994;1(32 Suppl):329-349. [PubMed: 7722796]

Mingot JM, Espeso EA, Diez E, Penalva MA. Ambient $\mathrm{pH}$ signaling regulates nuclear localization of the Aspergillus nidulans PacC transcription factor. Mol. Cell. Biol 2001;21:1688-1699. [PubMed: 11238906]

Mingot JM, Tilburn J, Diez E, Bignell E, Orejas M, Widdick DA, Sarkar S, Brown CV, Caddick MX, Espeso EA, et al. Specificity determinants of proteolytic processing of Aspergillus PacC transcription factor are remote from the processing site, and processing occurs in yeast if $\mathrm{pH}$ signalling is bypassed. Mol. Cell. Biol 1999;19:1390-1400. [PubMed: 9891072]

Muhlschlegel FA, Fonzi WA. PHR2 of Candida albicans encodes a functional homolog of the pHregulated gene $P H R l$ with an inverted pattern of $\mathrm{pH}$-dependent expression. Mol. Cell. Biol 1997;17:5960-5967. [PubMed: 9315654]

Penalva MA, Arst HN Jr. Recent advances in the characterization of ambient $\mathrm{pH}$ regulation of gene expression in filamentous fungi and yeasts. Annu. Rev. Microbiol 2004;58:425-451. [PubMed: 15487944]

Penalva MA, Tilburn J, Bignell E, Arst HN Jr. Ambient pH gene regulation in fungi: making connections. Trends Microbiol 2008;16:291-300. [PubMed: 18457952]

Ramon AM, Fonzi AW. Diverged binding specificity of Rim101p, the Candida albicans ortholog of PacC. Eukaryot. Cell 2003;2:718-728. [PubMed: 12912891]

Ramon AM, Porta A, Fonzi WA. Effect of environmental pH on morphological development of Candida albicans is mediated via the PacC-related transcription factor encoded by PRR2. J. Bacteriol 1999;181:7524-7530. [PubMed: 10601210]

Rollins JA, Dickman MB. pH signaling in Sclerotinia sclerotiorum: identification of a pacC/RIM1 homolog. Appl. Environ. Microbiol 2001;67:75-81. [PubMed: 11133430]

Saporito-Irwin SM, Birse CE, Sypherd PS, Fonzi WA. PHR1, a pH-regulated gene of Candida albicans, is required for morphogenesis. Mol. Cell. Biol 1995;15:601-613. [PubMed: 7823929]

Schmitt EK, Kempken R, Kuck U. Functional analysis of promoter sequences of cephalosporin C biosynthesis genes from Acremonium chrysogenum: specific DNA-protein interactions and characterization of the transcription factor PACC. Mol. Genet. Genomics 2001;265:508-518. [PubMed: 11405634]

Suarez T, Penalva MA. Characterization of a Penicillium chrysogenum gene encoding a PacC transcription factor and its binding sites in the divergent $p c b A B-p c b C$ promoter of the penicillin biosynthetic cluster. Mol. Microbiol 1996;20:529-540. [PubMed: 8736532]

Szaniszlo PJ. Molecular genetic studies of the model dematiaceous pathogen Wangiella dermatitidis Int. J. Med. Microbiol 2002;292:381-390.

Szaniszlo PJ, Hsieh PH, Marlowe JD. Induction and ultrastructure of the multicellular (sclerotic) morphology in Phialophora dermatitidis. Mycologia 1976;68:117-130. [PubMed: 6907]

Tilburn J, Sarkar S, Widdick DA, Espeso EA, Orejas M, Mungroo J, Penalva MA, Arst HN Jr. The Aspergillus PacC zinc finger transcription factor mediates regulation of both acid- and alkalineexpressed genes by ambient pH. EMBO J 1995;14:779-790. [PubMed: 7882981]

Vincent O, Rainbow L, Tilburn J, Arst HN Jr, Penalva MA. YPXL/I is a protein interaction motif recognized by Aspergillus PalA and its human homologue, AIP1/Alix. Mol. Cell. Biol 2003;23:16471655. [PubMed: 12588984]

Wang Q, Liu H, Szaniszlo PJ. Compensatory expression of five chitin synthase genes, a response to stress stimuli, in Wangiella (Exophiala) dermatitidis, a melanized fungal pathogen of humans. Microbiology 2002;148:2811-2817. [PubMed: 12213927]

Wang Q, Szaniszlo PJ. WdStuAp, an APSES transcription factor, is a regulator of yeast-hyphal transitions in Wangiella (Exophiala) dermatitidis. Eukaryot. Cell 2007;6:1595-1605. [PubMed: 17693595]

Wang Z, Szaniszlo PJ. WdCHS3, a gene that encodes a class III chitin synthase in Wangiella (Exophiala) dermatitidis, is expressed differentially under stress conditions. J. Bacteriol 2000;182:874-881. [PubMed: 10648509] 
Wang Z, Zheng L, Hauser M, Becker JM, Szaniszlo PJ. WdChs4p, a homolog of chitin synthase 3 in Saccharomyces cerevisiae, alone cannot support growth of Wangiella (Exophiala) dermatitidis at the temperature of infection. Infect. Immun 1999;67:6619-6630. [PubMed: 10569783]

Ye X, Szaniszlo PJ. Expression of a constitutively active Cdc42 homologue promotes development of sclerotic bodies but represses hyphal growth in the zoopathogenic fungus Wangiella (Exophiala) dermatitidis. J. Bacteriol 2000;182:4941-4950. [PubMed: 10940039]

Zheng JS, Sutton DA, Fothergill AW, Rinaldi MG, Harrak MJ, de Hoog, S G. Spectrum of clinically relevant Exophiala species in the United States. J. Clin. Microbiol 2007;45:3713-3720. [PubMed: 17596364]

Zheng L, Mendoza L, Wang Z, Liu H, Park C, Kauffman S, Becker JM, Szaniszlo PJ. WdChs1p, a class II chitin synthase, is more responsible than WdChs $2 p$ (Class I) for normal yeast reproductive growth in the polymorphic, pathogenic fungus Wangiella (Exophiala) dermatitidis. Arch. Microbiol 2006;185:316-329. [PubMed: 16544168]

Zheng L, Szaniszlo PJ. Cloning and use of the WdURA5 gene as a his $G$ cassette selection marker for potentially disrupting multiple genes in Wangiella dermatitidis. Med. Mycol 1999;37:85-96. [PubMed: 10361263] 
WdPacC AnPacC

WdPacC AnPacC

WdPacC AnPacC

WdPacC AnPacC

WdPacC AnPacC

WdPacC AnPacC

WdPacC AnPacC

WdPacC AnPacC

WdPacC AnPacC

WdPacC AnPacC

WdPacC AnPacC

WdPacC AnPacC

-MSELAETSTAGNNDNNNSNNNAPNSPNPTVEAAAAAAAAAAAAAVAASTPNPSTSQDVL 59 MLGAMAEEAVAPVAVPTTQEQPTSQPAAAQVTTVTSPSVTATAAAATAAVASP------- 53

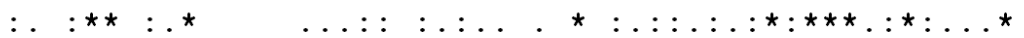

QQQGQFQQSQQQQPLVQNQPAPSVNSAGENLOCOWVGCGERCSTPEALYEHVCERHVGRK 119 QANG-----NAASPVA---PASST SRPAEELTCMWQGCSEKLPTPESLYEHVCERHVGRK 105

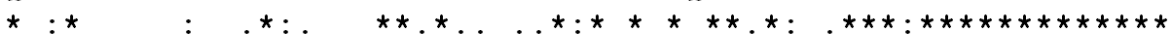

STNNLNLTCAWGTCRTTTVKRDHITSHIRVHVPLKPHKCEFCGKAFKRPODLKKHVKTHA 179 STNNLNLTCQWGSCRTTTVKRDHITSHIRVHVPLKPHKCDFCGKAFKRPQDLKKHVKTHA 165

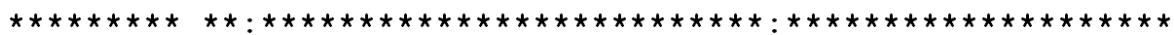

DDSVIMRS PNLE PNGGRQHQNGLPQGGDYASYYGHGLTGQVAQSYYAPAMPGPQDYTGQH 239 DDSVLVRSP--EP-GSRNPD---------MMFGGNFKGYAAAHYFEPALNPVPSQGYAH 212

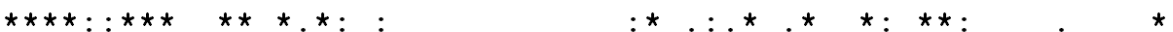

HHNQYYQPHPPVSSGHPGYGPVTYYS-TASTTSPYDYEARKRGYDALDHFFGQVKRRELD 298 GPPQYYQAHHAPQPSNPSYGNVYYALNTGPEPHQASYESKKRGYDALNEFFGDLKRRQFD 272

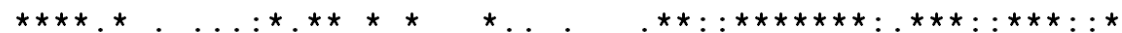

PINFHNI SRRLFELQGLQLPQI I PSSVPAPAYQPVSVGGAY----EAADPIQAYSLPPMG 354 PNSYAAVGQRLLSLQNLSLPVLTAAPLPEYQAMPAPVAVASGPYGGGPHPAPAYHLPPMS 332

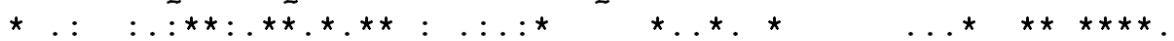

NAKTREDLTSIDQILEQMOATIYENDTHLGSANVGQSGSGYVA----YRTSNSPPSTSQQ 410 NVRTKNDLINIDQFLQQMODT I YENDDNVAAAGVAQPGAHY I HNGI SYRTTHSPP--TQL 390

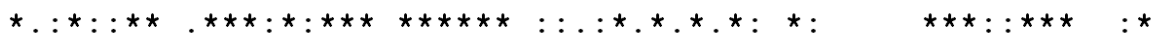

PSTAAQTNPTALLQNQTOSNVASNTDASTPGLTPPSSAQSYTSGHSPLQGHTAP--- - - 464 PSAHATTQTTAGPI ISNTS--AHSPSSSTPALTPPSSAQSYTSGRSPISLPSAHRVSPPH 448

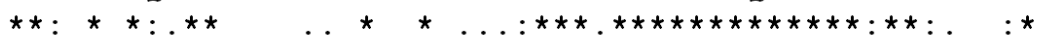

-SGNGLY PNLPSSASDMAY------AAANAATLSGIYDQEERRRYSGGMLQRAAPAK--V 515 ESGSSMY PRLPSATDGMTSGYTAASSAAPPSTLGGIFDNDERRRYTGGTLQRARPASRAA 508

$\star \star \ldots: * * . * *:: \ldots *$ :

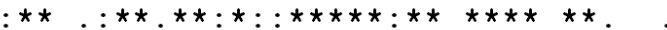

KDEMDITSD----GSVTPPASALNQQNKDKKSASPQENVIDPALAAEAAST PKSDPRDAD 571 SESMDLSSDDKESGERT PKQI SASLIDPALHSGSPGEDDVTRTAKAATEVAERS----D 563

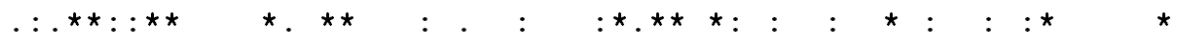

QEQVWVQNMRLIEWMREF IKKKLQSGDYEEENGHGGSPHHG---------------- 612 VQSEWVEKVRLIEYLRNY IANRLERGEFSDDSEQEQDQEQEQDQEQEQDQEQGQDRVSRS 623

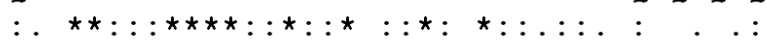

--GQLDHDMSGT SDQKHDKS-------------EEEQLYPVLRHVEESA------ 646 PVSKADVDMEGVERDSLPRSPRTVPIKTDGESAEDSVMYPTLRGLDEDGDSKMPS 678

$$
\text { .: **.*. : . : * } \quad *: .: * * *:: * \ldots
$$

Fig. 1.

Multiple alignment of the PacC protein of $W$. dermatitidis with its closely related ortholog in A. nidulans by the CLUSTALW program. A. nidulans (AnPacC) accession \#: EAA63426: stars indicate the identical amino acids, two dots show the similar amino acids, and single dots present the less conserved amino acids. The three zinc finger motifs are underlined with thick lines. The processing protease cleavage site and the signaling protease box [according to AnPacC ( Penalva and Arst, 2004)] are indicated by thin lines. The ending points of PacC ${ }^{+/-}$ and $\mathrm{PacC}^{\mathrm{C}}$ trunctations in the $W$. dermatitidis mutants are shaded. 

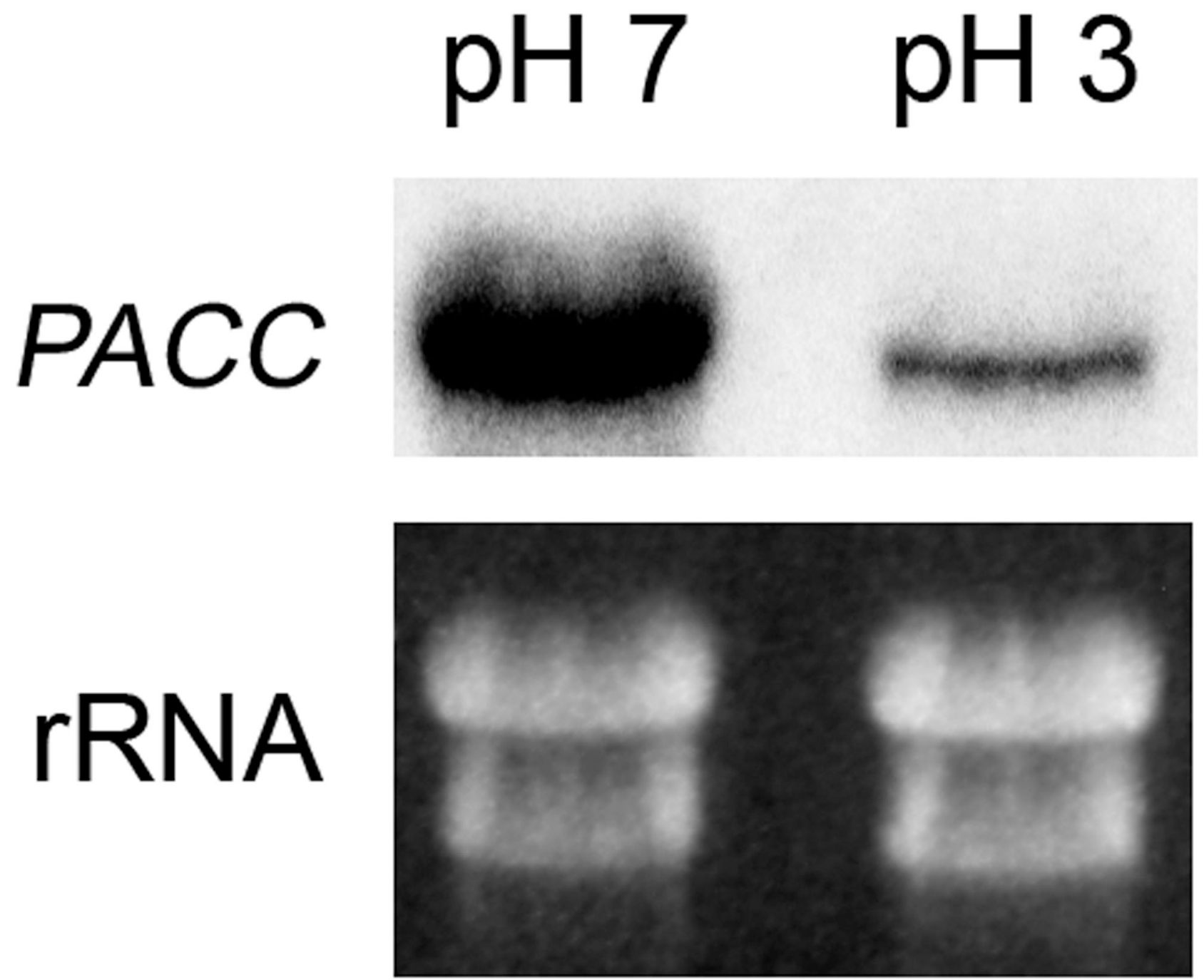

Fig. 2.

Northern analysis of PACC expression.Total RNA prepared from wild-type cells of $W$. dermatitidis grown in $\mathrm{pH} 7$ and $\mathrm{pH} 3 \mathrm{MCDB}$ liquid media at $25^{\circ} \mathrm{C}$ for $24 \mathrm{~h}$ was hybridized with a $P A C C$ probe. 

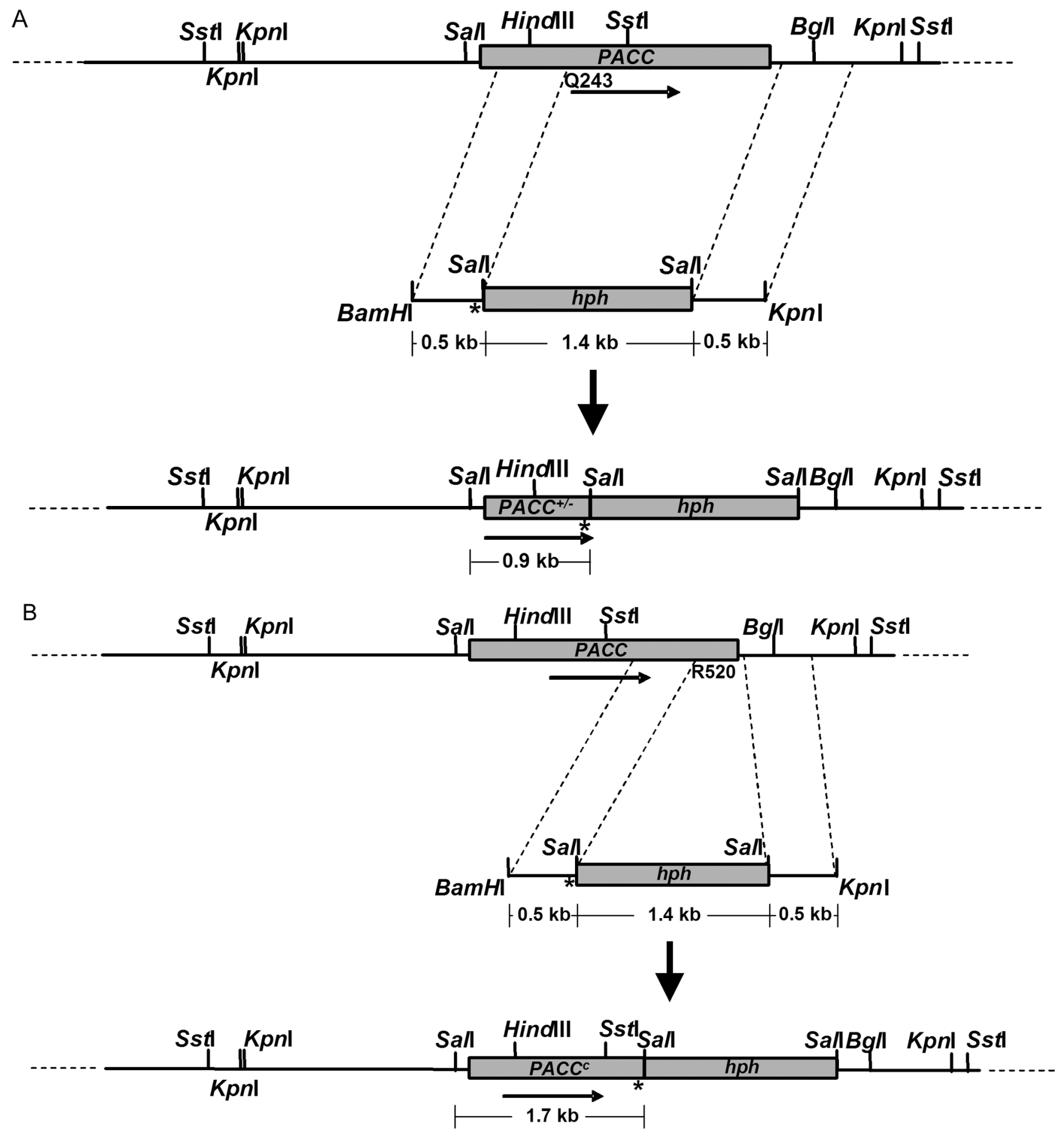

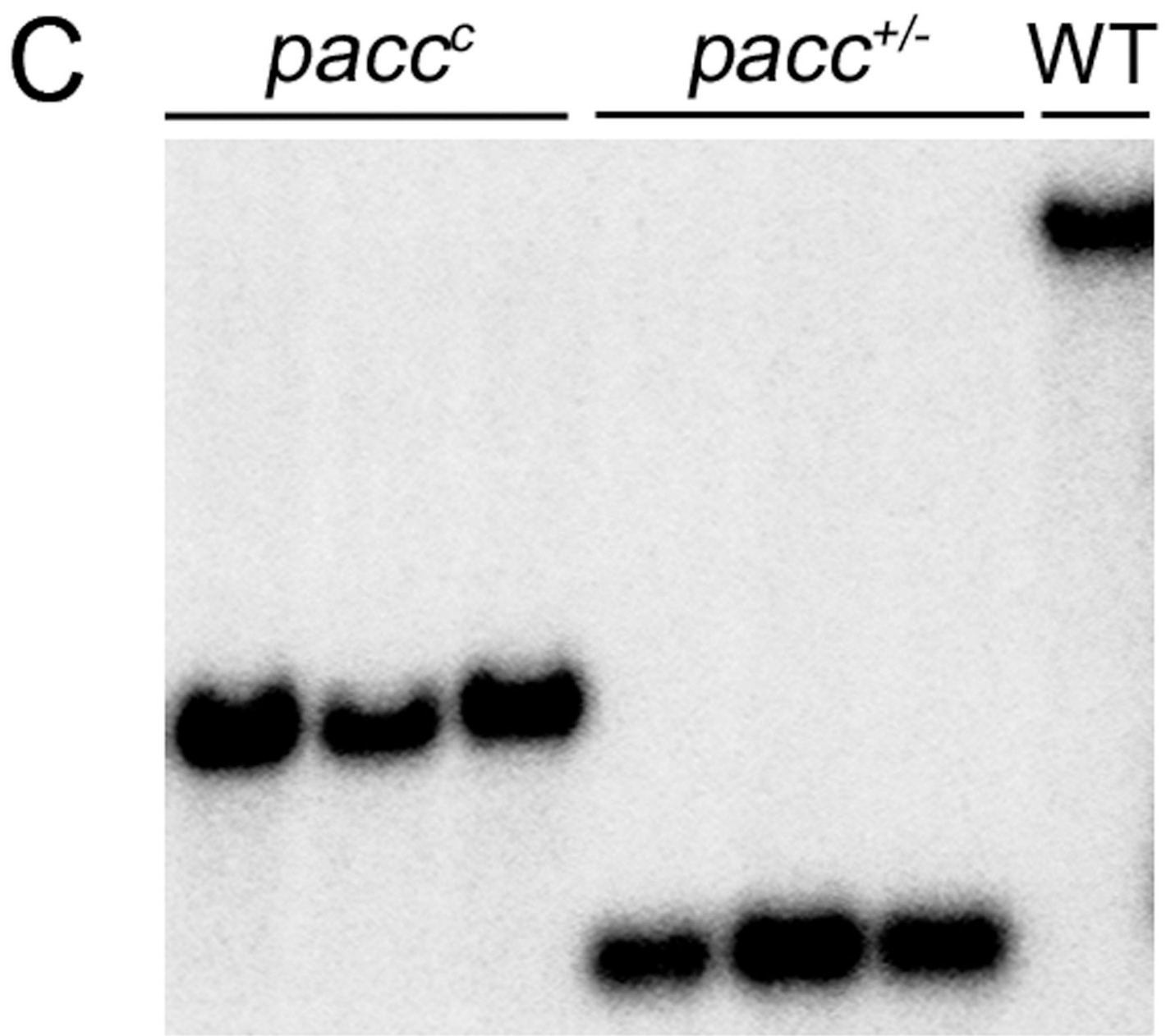

$7 \mathrm{~kb}$

$1.7 \mathrm{~kb}$

$0.9 \mathrm{~kb}$ 


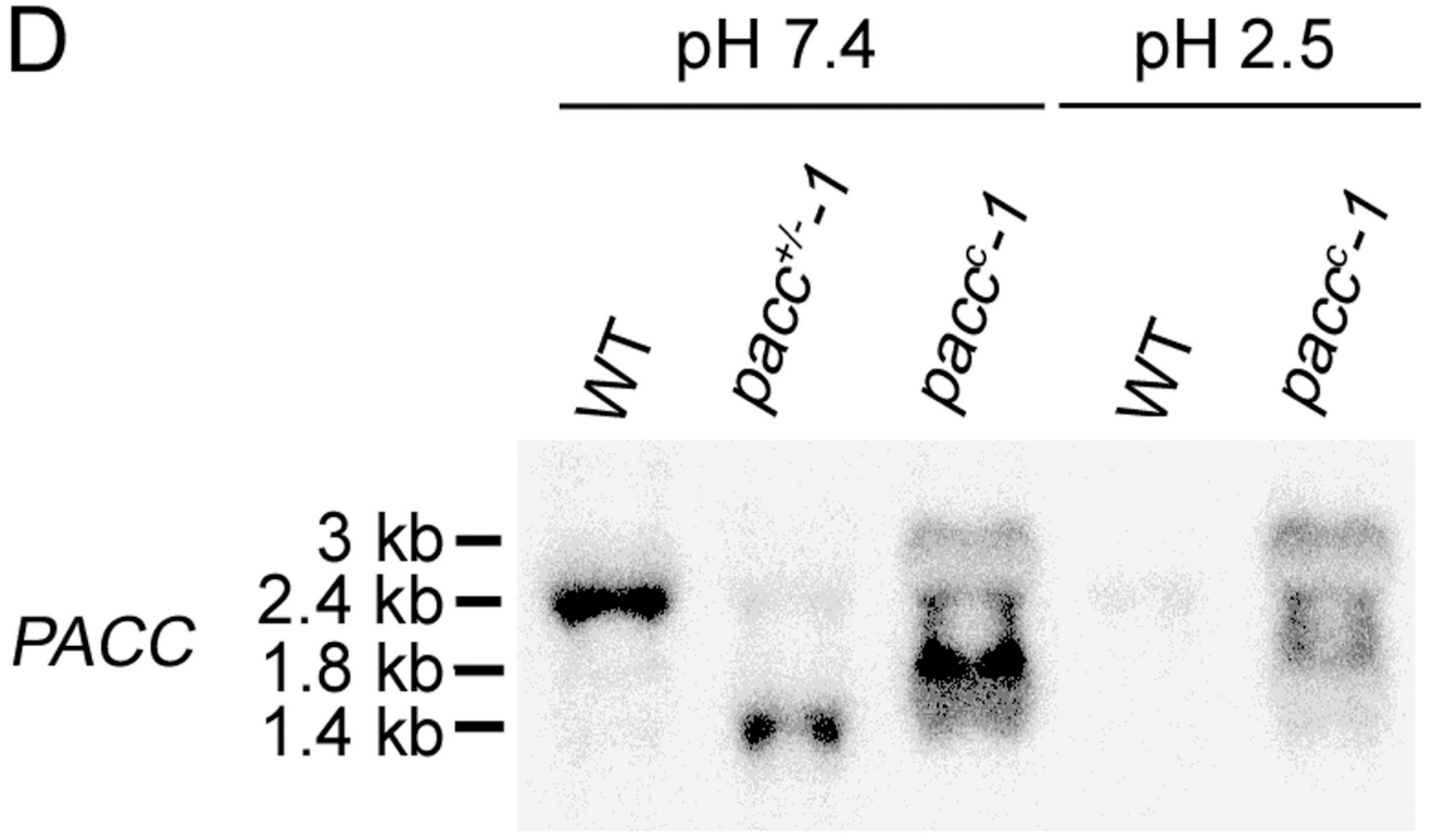

\section{rRNA}

Fig. 3.

Construction of the PACC mutations by a one-step gene replacement method. (A) Strategy for the construction of $\mathrm{pacc}^{+/-}$A $0.5-\mathrm{kb} 5$ ' fragment and a $0.5-\mathrm{kb} 3^{\prime}$ ' fragment were constructed to flank the $h p h$ marker. This fragment was transformed into $W$. dermatitidis to produce a recombination with genomic DNA. A Stop codon was introduced at the end of the 5' sequences after Q243, which is denoted by a star. (B) Strategy for the construction of $p^{2} c^{c}$ A $0.5-\mathrm{kb} 5$, fragment and a $0.5-\mathrm{kb} 3$ ' fragment were constructed to flank the $h p h$ marker. This fragment was transformed into $W$. dermatitidis to produce a recombination with genomic DNA. A stop codon was introduced at the end of the 5' sequences after R501, which is denoted by a star. (C). Southern analysis. Genomic DNA of the wild-type strain and mutation strains were digested with SalI and electrophoresed on a $0.8 \%$ agarose gel. DNA was hybridized with the 204-bp PACC probe, which is indicated by the horizontal arrows. The sizes of the hybridization bands are indicated. (D). Northern analysis. RNA of the wild-type strain and mutation strains grown in $\mathrm{pH} 7.4$ and $\mathrm{pH} 2.5$ MCDB media was hybridized with the 204-bp PACC probe. The sizes of the hybridization bands are indicated. 


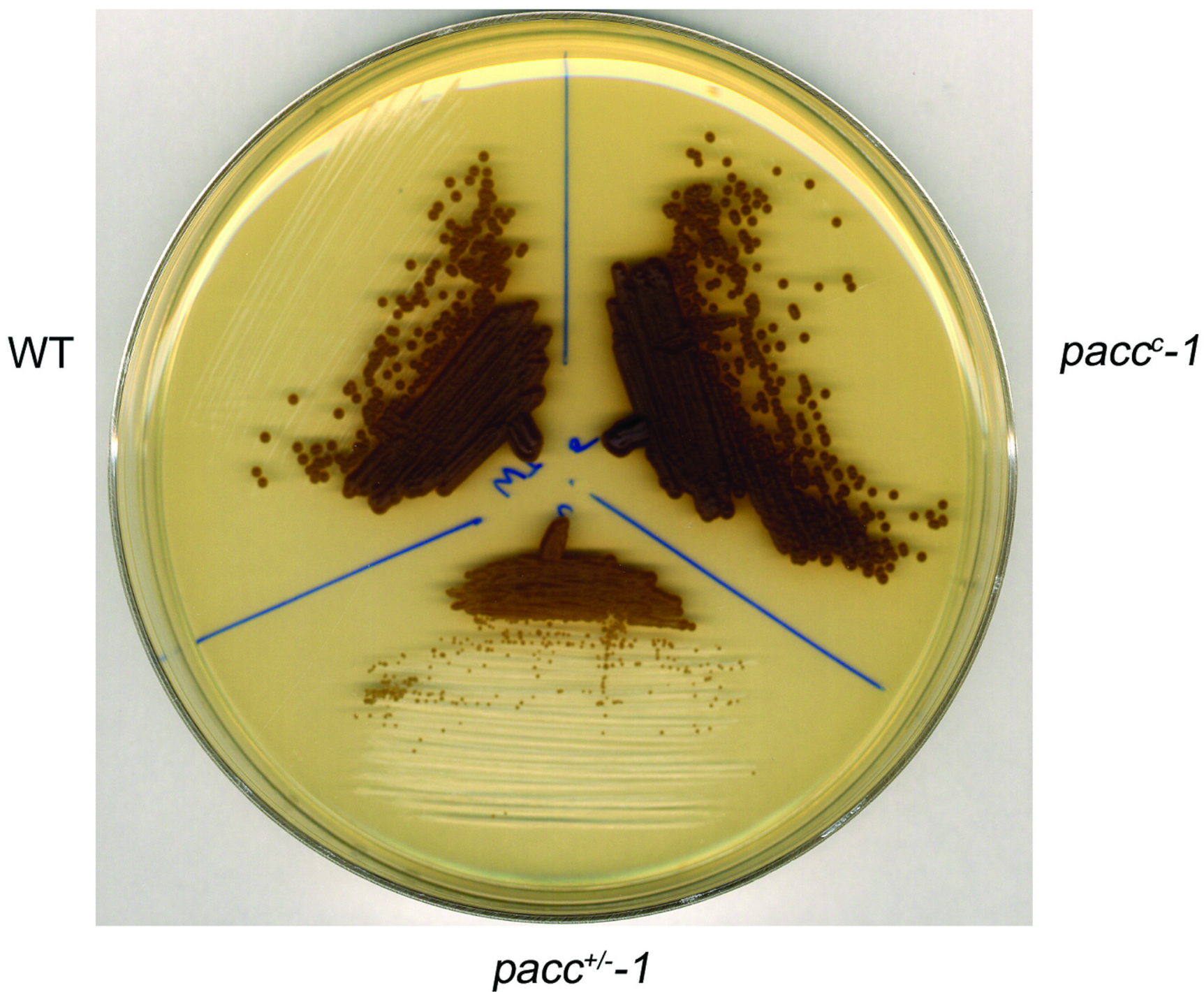

Fig. 4.

The $\mathrm{pacc}^{+-}-1$ mutant grew slower than the WT and the $\mathrm{pacc}^{\mathrm{c}-1}$ mutant when cultured under the standard condition. Yeast cells of the WT, $\mathrm{pacc}^{\mathrm{C}-1}$ and $\mathrm{pacc}^{+-}-1$ were streaked on YPDA and incubated at $25^{\circ} \mathrm{C}$ for 5 days before photography. 


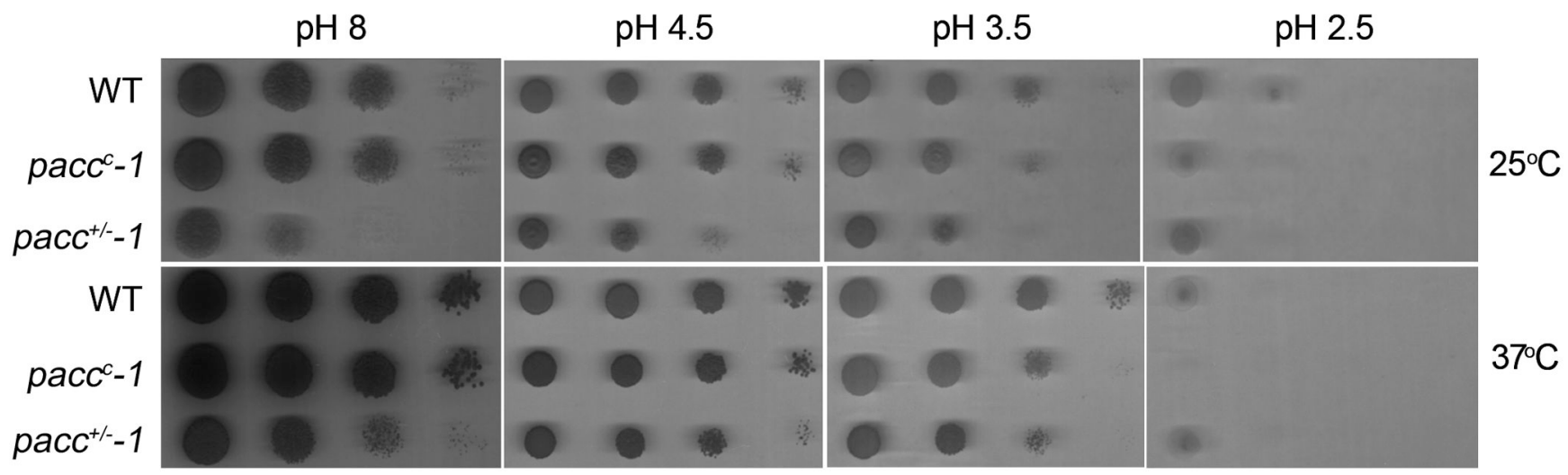

Fig. 5.

The PACC mutants were affected by different $\mathrm{pH}$ conditions on YPDA. Spot assays: WT, pacc $^{c-1}$ and $\mathrm{pacc}^{+/-}-1$ yeast cells were 10 -fold diluted, spotted and incubated $25^{\circ} \mathrm{C}$ and $37^{\circ} \mathrm{C}$ for 3 days before photography. The $\mathrm{pacc}^{+/-}-1$ mutant grew poorer at $\mathrm{pH} 8$ than at acidic $\mathrm{pH}$, compared with the wild type. The growth of the $\mathrm{pacc}^{c-1}$ mutantwas reduced at $\mathrm{pH} 3.5$ and $\mathrm{pH} 2.5$ compared to the wild type. 

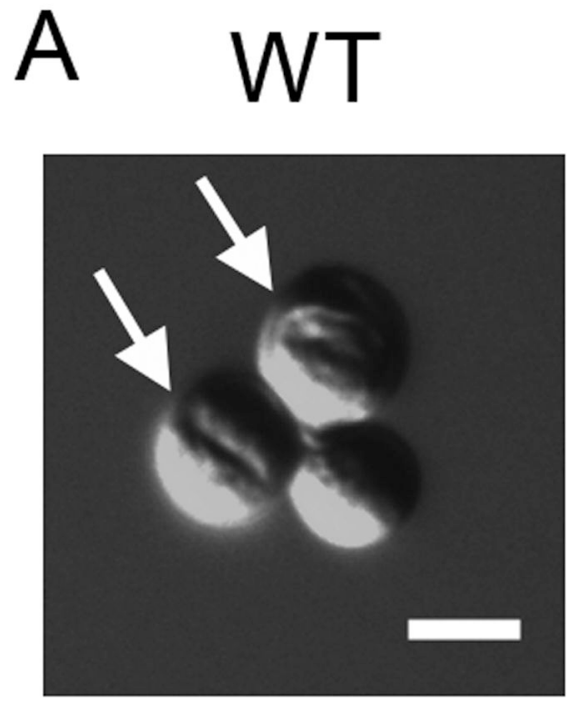

$\operatorname{pacc}^{+/-1}$

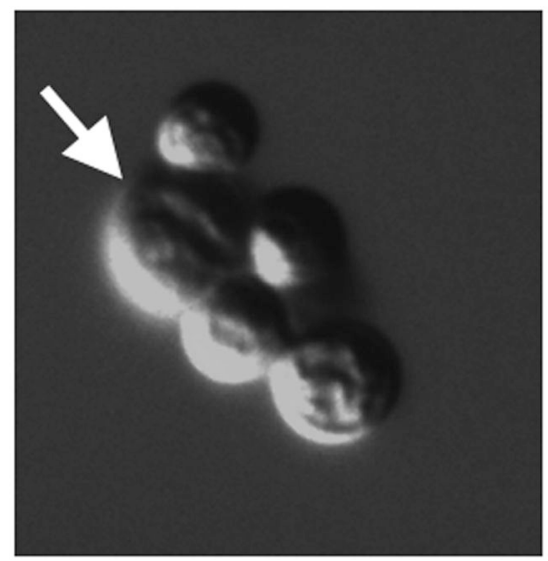

pacc -1

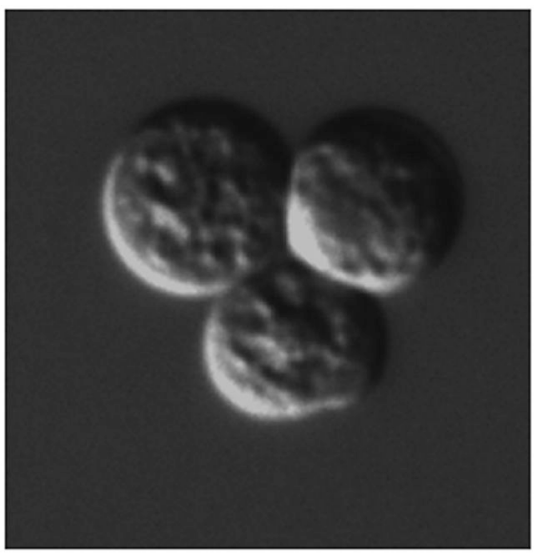

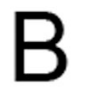

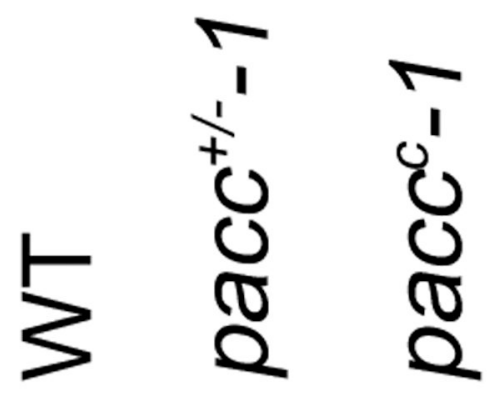

\section{CHS1}
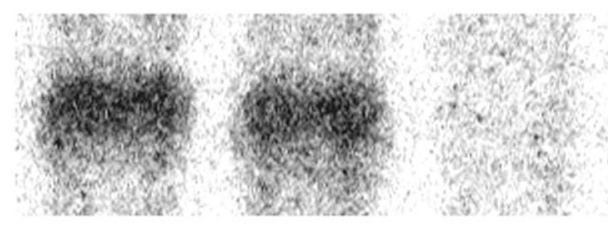

rRNA

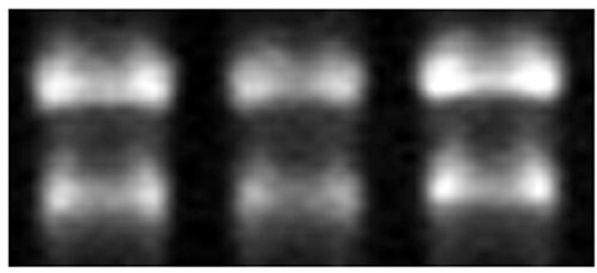

Fig. 6.

At acidic $\mathrm{pH}$ pacc $^{\mathrm{c}}-1$ was not impaired in isotropic growth but septation of the resulting sclerotic cells did not occur. (A) pacc ${ }^{c}-1$ grown in $\mathrm{pH} 2.5 \mathrm{MCDB}$ at $25^{\circ} \mathrm{C}$ was affected in sclerotic form production. After 2 days, cells were photographed with a light microscope fitted with a $100 \mathrm{x}$ oil objective. WT and $\mathrm{pacc}^{+/-}-1$ had begun producing sclerotic cells and planate cells. Representative planate cells in the WT and $\mathrm{pacc}^{+/-}-1$ are indicated by arrows. All the cells of the paccc-1 mutant swelled more than those of the WT cells, implying that solutes and water had entered and inflated the cells. The scale bar represents $5 \mu \mathrm{m}$ and is applicable to each image. (B) CHSl expression was affected by the PACC constitutive mutation. Total RNA was prepared from cells grown in $\mathrm{pH} 2.5 \mathrm{MCDB}$ at $25^{\circ} \mathrm{C}$ for 2 days. The $10 \mu \mathrm{g}$ RNA was loaded 
and hybridized with a $C H S 1$ probe. $C H S 1$ expression was largely decreased in the pacc $^{c-1}$ mutant compared with that of the wild type and the $\mathrm{pacc}^{+-}-1$ mutant at $\mathrm{pH} 2.5$. The decreased expression of CHS1 may contribute to the poorer growth of pacc $^{c}-1$ at acidic $\mathrm{pH}$. 


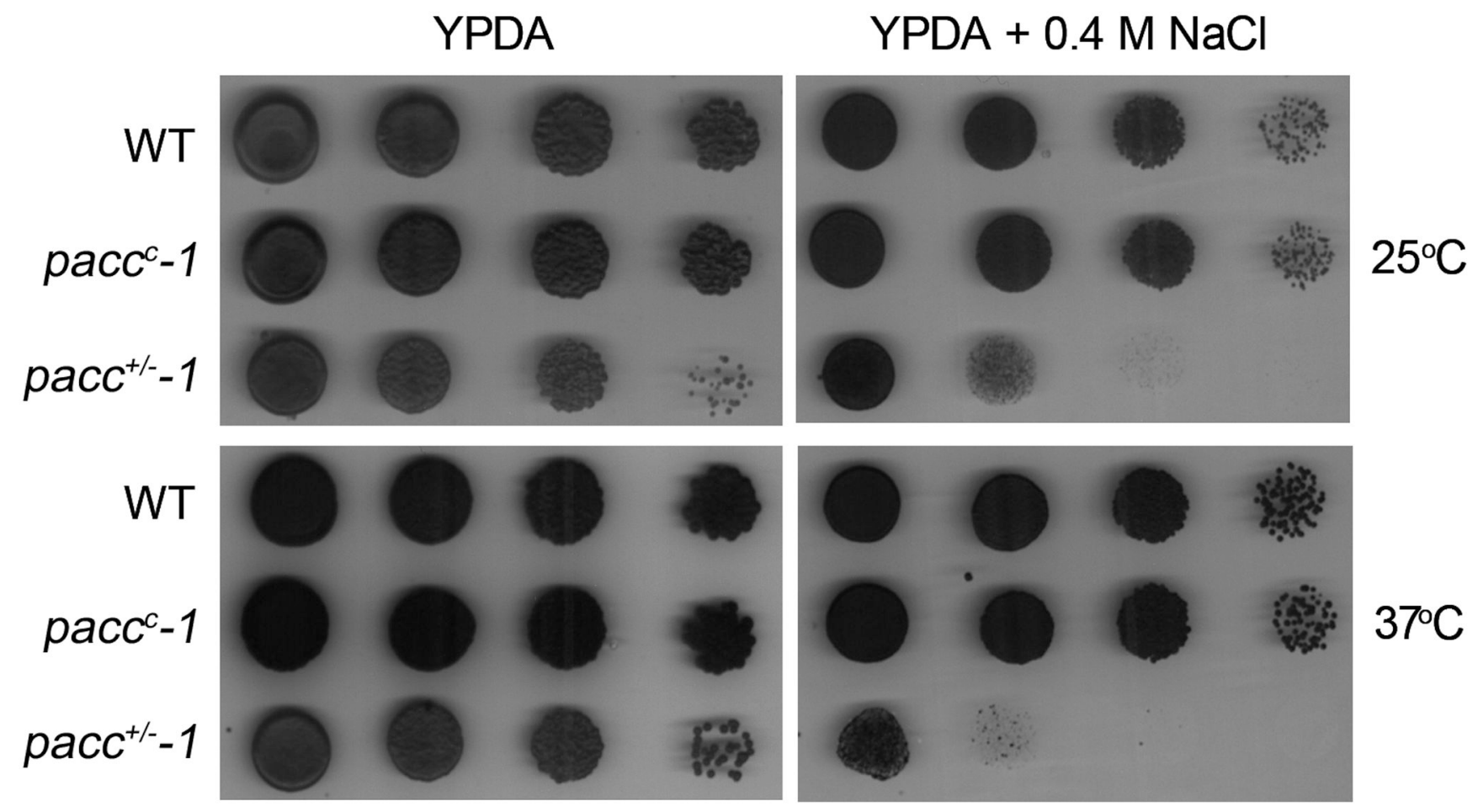

Fig. 7.

The pacc $^{+/-}-1$ mutant was more sensitive to $\mathrm{Na}^{+}$stress. Spot assays. WT, pacc ${ }^{c-1}$ and pacc $^{+/-}-1$ cells were $10-$ fold diluted, spotted and incubated at $25^{\circ} \mathrm{C}$ and $37^{\circ} \mathrm{C}$ for 4 days. The $\mathrm{pacc}^{+/-}-1$ mutant grew poorer on YPDA $+0.4 \mathrm{M} \mathrm{NaCl}$ than on YPDA, compared with the wild type and the pacc $^{c}-1$ mutant. 


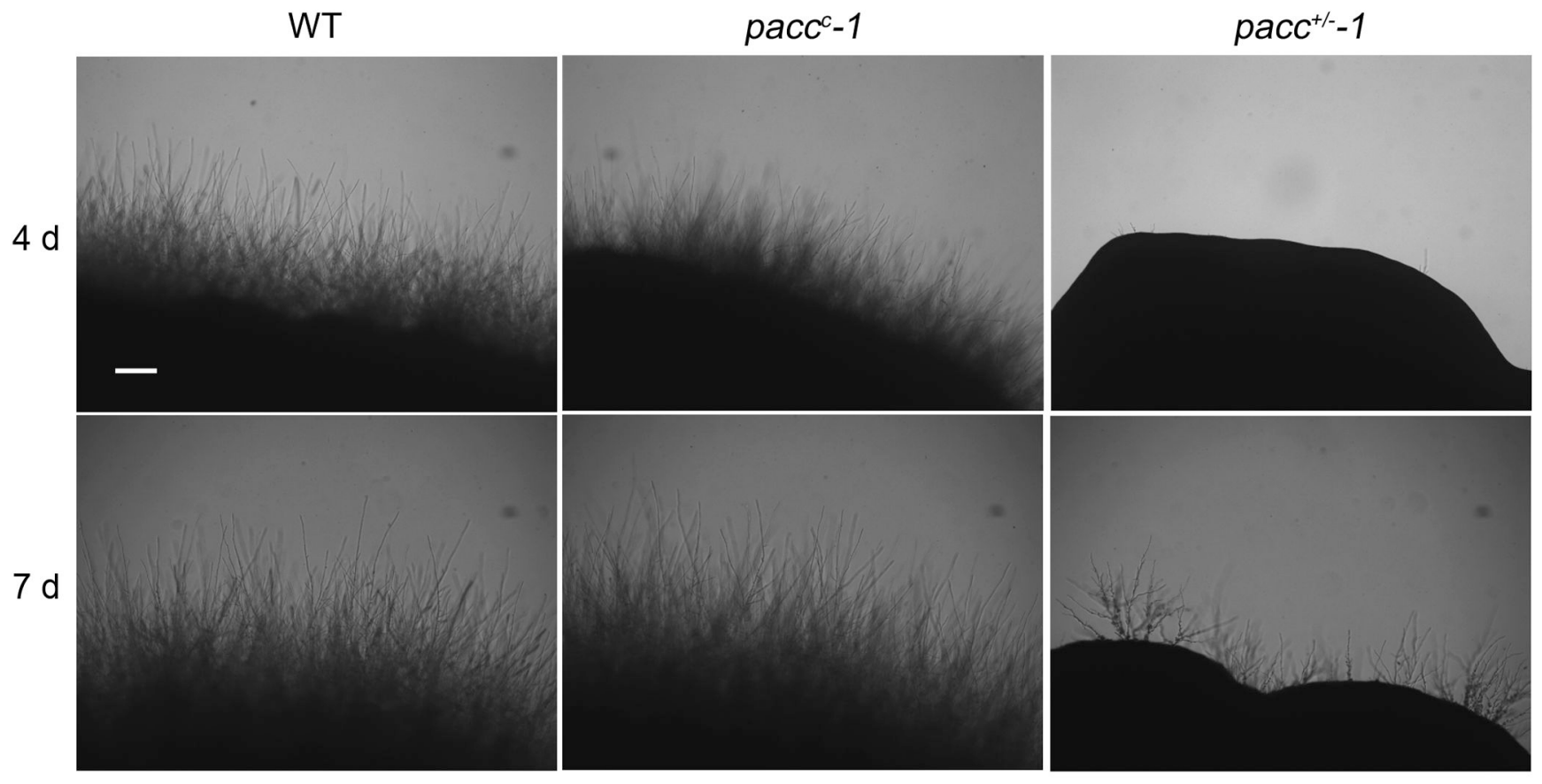

Fig. 8.

The PacC protein regulated filamentous growth in $W$. dermatitidis. Yeast cells of the WT and the pacc $^{c-1}$ and pacc $^{+/-}-1$ mutants were spread in a block on PDA, respectively, and then incubated at $25^{\circ} \mathrm{C}$. At the times indicated, the colony edges were photographed with a light microscope fitted with a $5 \mathrm{x}$ objective. The $\mathrm{pacc}^{+/-}-1$ mutant produced only a few filaments at the edges of the agar medium even after 7 days of incubation, whereas the wild type and the pacc $c^{-}-1$ mutant produced many filaments at the edge even at 4 days of incubation. The scale bar is $0.2 \mathrm{~mm}$ and is applicable to all the growth in the figure. 

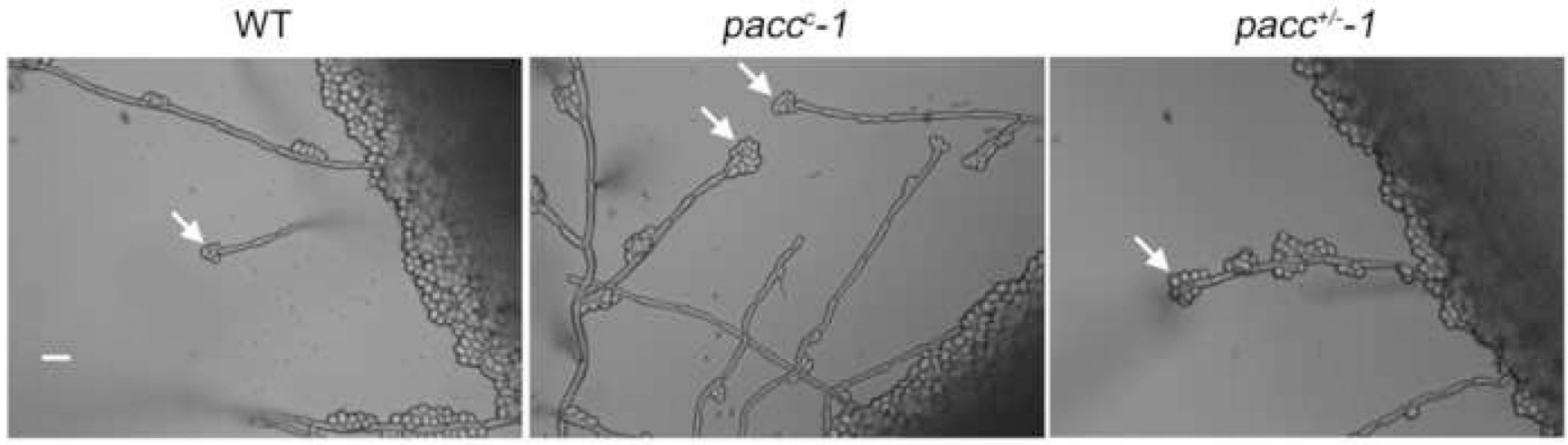

Fig. 9.

The pacc $^{+/-}-1$ mutation did not block conidiogenesis. The WT and the pacc $^{c-1}$ and pacc $^{+/-}-1$ mutants were inoculated on PDA in slide cultures and incubated at $25^{\circ} \mathrm{C}$. After two weeks of incubation, conidiophores and conidia were photographed with a compound light microscope fitted with a 63 x objective. The clusters of conidia are indicated by arrows. The scale bar represents $10 \mu \mathrm{m}$ and is applicable to all the growth in the figure. 